\title{
Vistas sobre arte africana no Brasil: lampejos na pista da autoria oculta de objetos afro- brasileiros em museus'
}

\author{
Marta Heloísa (Lisy) Leuba Salum²
}

RESUMO: Examinando objetos relacionados aos antigos candomblés preservados em coleções, Marianno Carneiro da Cunha perfilou uma tradição estética nagô-iorubana criada no Brasil que tem sido considerada como uma das primeiras formulações da arte afro-brasileira, se não uma continuidade da arte africana no Brasil. Expandimos a amostragem enraizada nessa tradição descrita por esse estudioso, chegando a um novo corpus que apresentamos neste artigo, tentando estabelecer as potencialidades da análise estilística que ele empregou, e introduziu no Brasil, como procedimento metodológico no estudo da cultura material de origem africana. Os dados obtidos revelam que, muito além do que originalmente representam, esses objetos podem se constituir apenas em um repertório visual emblemático de abordagens híbridas da produção acadêmica sobre as culturas africanas tanto quanto sobre o negro no Brasil, caso eles não venham a ser retomados através das suas expressões de materialidade próprias e individuais.

PALAVRAS-CHAVE: Coleções etnográficas. Estilística (escultura africana). Estudos africanistas. Museus (Brasil).

Views on African art in Brazil: lightings in the track of the hidden's authorship of the Afro-Brazilian objects in museums

ABSTRACT: In examining objects preserved in collections related of ancients Candomble's Terreiros, Marianno Carneiro da Cunha finded out and profiled a Nago-Yoruba aesthetic tradition created in Brazil that have been considered as one of the first form of Afro-Brazilian Art, or a continuation of African Art in Brazil. We expanded the schollar's established sampling rooted in this tradition in gathering a new corpus presented in this article, in trying to set potentialities of the stylistic analysis that he used and introduced in Brazil as a methodological procedure employed in the study of material culture of African origin. The obtained data reveal that these objects, far beyond from what they originally represent, can constitute merely an emblematic visual repertoire of the hybrid approaches adopted in the Brazilian academic production on the Black in
1. Antes de tomar sua forma atual, este artigo se constituía da primeira parte de um só texto escrito entre 2013 e 2014 . Vendo-se antes publicada sua parte análoga e sequencial sob o título de "Estilos de escultura em peregrinação...", ele se manteve inédito, com o nome provisório de "Mãos de artista, obras anônimas: marcas de um Brasil africano ou de uma África brasileira em objetos de museu". Posteriormente, depois de aprovado para publicação nos Anais do Museu Paulis$t a$, ele passou a ter o título com que se apresenta aqui.

2. Professora do Museu de Arqueologia e Etnologia da Universidade de São Paulo e membro do Núcleo de Apoio à Pesquisa Brasil África da Pró-Reitoria de Pesquisa da mesma universidade.E-mail: <lisymhls@ usp.br>. 
the country, just as on African cultures, if these objects are not retaked under of self-expressions of materiality.

KEYWORDS: Ethnographical Collections. Stylistic (African Sculpture). Africanist Studies. Museums (Brazil).

Introdução ao assunto e as primeiras publicações

Este artigo expõe uma experiência de interpretação de objetos em coleções atribuídos aos antigos candomblés, a partir da formação prévia de um corpus composto de esculturas publicadas por estudiosos da primeira metade do século XX. Seu núcleo é constituído por uma seleção de objetos feita por Marianno Carneiro da Cunha, conforme publicada em Arte Afro-brasileira em 1983, pela qual ele estipulou uma tradição escultórica africana no Brasil. A partir de então, essas esculturas vêm sendo consideradas uma das primeiras formas da arte afrobrasileira, o que se consagrou através de A mão afro-brasileira, de Emanoel Araujo, cuja primeira edição se deu em 1988 e gerou seu acumulado trabalho de curadoria sobre o assunto pelo qual é mundialmente reconhecido.

Entre os estudiosos anteriores, não há quem não se tenha curvado diante do valor estético dessas esculturas que vinham sendo apreendidas dos cultos africanos no Brasil pela Polícia da Corte, órgão militar vigente ao longo da monarquia do Brasil oitocentista. Nesse contexto de descoberta, seus aspectos estilísticos e tecnológicos foram tragados por correntes de pensamento que, desde o final do século XIX, se entrecruzaram durante um duradouro processo assistemático subjacente aos interesses acadêmicos despertados sobre o negro e os desdobramentos socioculturais do escravismo africano no Brasil e nas Américas.

Algumas dessas esculturas foram integradas a museus muito precocemente, como as publicadas em $\bigcirc$ fetichismo dos negros do Brazil, de Etienne Brazil, em 1911, e que se encontram no Museu Nacional do Rio de Janeiro (MNRJ, Rio de Janeiro/RJ). Mas, sem afinidades estilísticas com as peças analisadas por Marianno, elas foram tratadas em outro artigo. Aqui vamos considerar os dois outros lotes antigos, sem método de coleta declarado, mas feita nos candomblés na Bahia até durante os anos 1920. Muitas não existem mais, ou não se sabe onde se encontram; as poucas estatuetas que remanescem do passado constituem coleções em instituições museológicas.

Antes da publicação de A arte negra no Brasil, de Arthur Ramos, em 1949, as esculturas colhidas pelo autor, em 1925 e 1927, já haviam sido publicadas por ele na primeira edição de $\bigcirc$ negro brasileiro: ethnographia religiosa e psychanalyse, de 1934. Já o conjunto de peças do "candomblé gêge-iorubano", o primeiro lote desse tipo de peça publicado, foi coletado no final do século XIX e 
deu origem ao artigo pioneiro de Nina Rodrigues em 1904, "As bellas-artes nos colonos pretos no Brazil: a esculptura".

Até a metade do século XX, nenhuma outra peça congênere veio a ser difundida, mantendo-se a abordagem artística desse tipo de escultura sob conceitos enviesados de raça e aculturação. Chegou-se ao ponto em que, dessa abordagem, surgiu uma alusão à inexistente democracia racial e social no Brasil. Ela foi combatida por uma sociologia brasileira emergente nesse período, o que, também, condicionou o estudo dos candomblés na sua integralidade, enquanto religião. Com isso, o estudo da cultura material africana no Brasil, que vinha sendo feito através dessas esculturas e fora do contexto social de origem, se arrefeceu. Mas, na década de 1930, com o impacto provocado por novas esculturas apreendidas no auge da repressão policial aos terreiros da Bahia junto aos primeiros congressos afro-brasileiros ocorridos no mesmo período, elas vieram a ser recobradas por estudiosos de outras áreas, como Mário Barata em A escultura de origem africana no Brasil, de 1957.

Constata-se que foi por essas esculturas desses anos 1930 e 1940 que Marianno formou sua seleção. Ele morreu precocemente, sem dar continuidade a suas pesquisas, mas afere com fervor, nas páginas iniciais em Arte afro-brasileira, de sua autoria e publicado postumamente, em 1983, necessária interdisciplinaridade entre arqueologia, antropologia e história que os estudos de cultura material e da arte deviam e ainda devem aos objetos dos antigos candomblés.

$\bigcirc$ núcleo de nosso corpus, que aqui iremos apresentar, portanto, abrange esculturas de três períodos compreendidos na transição entre os séculos XIX e XX, até aproximadamente 1940. Começamos o artigo com uma discussão bibliográfica sobre dois aspectos metodológicos fundantes em sua formação, vendo-se que, em seu terceiro item, essa discussão acaba por se fundir no exame e na interpretação dos objetos e dos dados que o corpus nos aprovisiona.

A devida autoria incógnita da arte afro-brasileira

Em 1904, na primeira página de seu artigo "As bellas-artes nos colonos pretos do Brazil: a esculptura", Nina Rodrigues apresenta um "grupo de oito figuras do culto gêge-nagô", como ele legenda a fotografia em que esse grupo é visto (Figura 1).

No corpo do artigo, Nina diz serem "peças diversas do culto gêgeyorubano dos orichás ou vôdus, tomadas às praticas d'essa religião, sobrevenientes nos nossos negros". 3 São os primeiros objetos dos candomblés publicados, mas não se sabe ao certo de seu paradeiro.

Perto de um século depois, Angela Lühning, analisando artigos de jornais que se referem às invasões e apreensões policiais no candomblé baiano entre 1919 e 1942, atribui a peças de culto do mesmo gênero função de provas reais da perseguição sofrida pelo povo de santo na época. ${ }^{4}$ Essa perseguição os
3. Rodrigues (2002, p. 159).

4. Lühning (1995-1996, p. 195-196). 
membros e os terreiros sofrem até hoje, de modo que esses artigos têm também o papel de testemunhar o descompromisso com o alcance da potencialidade dessas peças como documento cultural e histórico nas coleções dos museus.

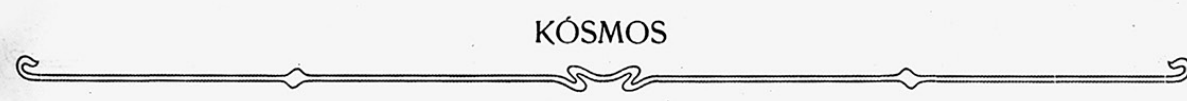

AS BELLAS-ARTES
NOS
COLONOS PRETOS DO BRAZIL
A ESCULPTURA

Era uma injustiça, mas era antes de tudo um erro.

$\mathrm{E}$ por isso, reivindicando os direitos da verdade, a observação desapaixonada dos factos havia de, infallivel, um dia rehabilitar os negros, dos exaggeros d'essa condemnação tão summaria quanto infundada.

Em verdade, nas levas de escravos que, por quatro longos seculos, o trafico negreiro, de continuo, vomitou nas plagas americanas, vinham, de facto, innumeros re-

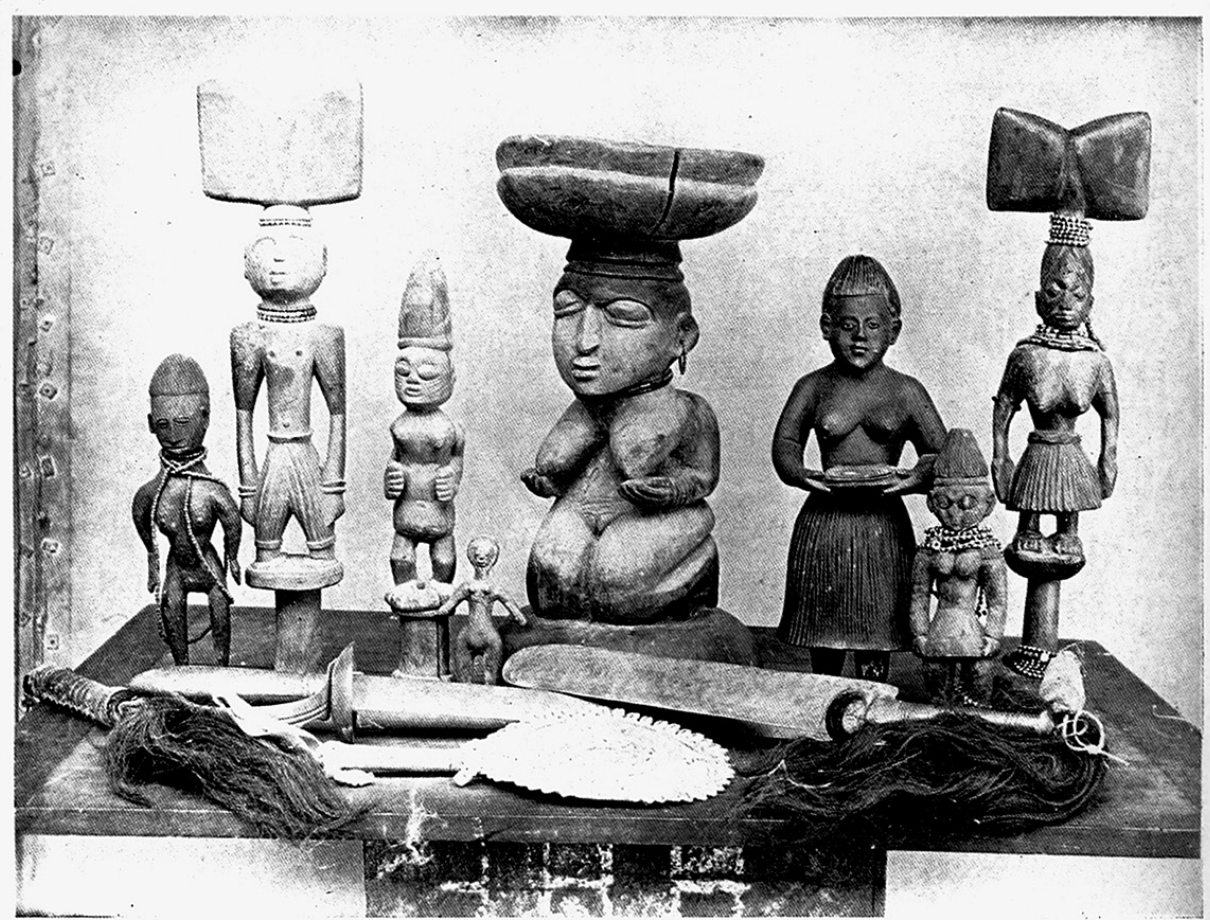

FIG. I-GRUPO DE OITO FIGURAS DO CULTO GÉGE-NAGÔ

(NA NUMERAÇÃo ADOPTADA NO TEXTO, AS FIOURAS OU PEÇAS São CONTADAS DA ESQUERDA PARA A DiREITA)

natural menosprezo que votam aos escravisados as classes dominadoras constituio sempre, e por toda a parte, perenne ameaça de falseamento para os propositos mais decididos de uma estimativa imparcial das qualidades e virtudes dos povos submettidos.

E foi por não ter cerrado ouvidos ás suggestões desses preconceitos que escriptores patrios conseguiram dar proporções de uma crença geral á de que os escravos negros, que com os Portuguezes e os Indios colonisaram Brazil, pertenciam todos aos povos africanos mais estupidos e boçaes. presentantes dos povos africanos mais avançados.em cultura e civilização.

As manifestacōes da sua capacidade artistica na pintura e na esculptura, - as mais intellectuaes das BellasArtes, - melhor o attestarão agora do que o poderam faArtes, - melhor o attestara

Pouco sabemos da pintura negra que, mesmo em Africa, não parece ter ido além de toscos desenhos, utilisados na ornamentação dos seus edificios, palacios, egrejas ou pegis.

Todavia, assim rudimentar, este esboço d'arte permittio a creaçăo, no Dahomey, de uma escriptura ideogra- 
Nas últimas décadas, os estudos de arte e cultura material vêm apresentando metodologias de investigação entre objetos, etnografia e imperialismo a partir da diversidade da documentação escrita e visual existente, como a fotografia colonial. 5 Fotografias "de época" podem e devem ser consideradas como fonte no estudo das coleções africanas e afro-brasileiras, mas, como se vê por esses autores, os testemunhos fotográficos não se bastam, mesmo que ampliem a perspectiva de análise e interpretação dos objetos em coleções.

Angela Lühning sinaliza:

Os artigos que falam sobre as chamadas "batidas" nos candomblés são, muitas vezes, acompanhados por uma foto, que mostra as peças apreendidas pela polícia. Às vezes são peças que existem em qualquer candomblé, outras vezes são peças únicas, tambores com alguma inscrição, roupas de santos, certas ferramentas bem originais, permitindo facilmente um reconhecimento (...). ${ }^{6}$

Mas o tratamento dado aos objetos apreendidos, além de neutralizá-los em seu valor intrínseco e comprometer a possibilidade de continuidade de seu uso social que o confisco implica, situa-os no meio da generalidade do que os institutos geográficos e históricos e museus de polícia receptavam na época, o que é bem condizente com sua condição, imposta, de discrepância. A autora assinala o teor pejorativo do tratamento dado a essas peças. Em um trecho das falas dos policiais, que a estudiosa analisa e transcreve em seu artigo, lê-se: "o Instituto ganha a sua parte: - as bugingangas e os troços". ?

Sendo assim, a potencialidade que se espera da fotografia na compreensão direta desses objetos extrapola seu valor material, técnico ou estético. A intenção do confisco - proibindo seu uso e constrangendo quem os fabrica e utiliza - é manter sua eficácia sob controle, como dizem Ulisses Rafael e Yvonne Maggie em seu artigo de 2013 sobre "objetos de magia" do Museu da Polícia Civil do Estado do Rio de Janeiro (Rio de Janeiro/RJ) e da Coleção Perseverança do Instituto Histórico e Geográfico de Alagoas (Maceió/AL). ${ }^{8}$ Esses autores interpelam outra das dimensões dos objetos de cultos afro-brasileiros, e das coleções em que se integram, que mostra a interposição de políticas hegemônicas de controle e noções de patrimônio e identidade. É esta a dimensão dos objetos que a documentação fotográfica do passado relativa à cultura material africana, no Brasil e na África, explicita: o tratamento pejorativo e seu cerceamento enquanto expressão coletiva de um fenômeno. Roger Sansi-Roca ${ }^{9}$ analisa, com especial vigor, a agência dessa cultura material existida, e ainda existente na Bahia, que mobiliza o próprio "povo de santo", tratando de sua repercussão através da museografia de objetos confiscados dos candomblés, expostos no Museu Estácio de Lima. Mesmo assim, o nome extensivo desse museu expressa sua missão: Museu Estácio de Lima do Instituto Médico-Legal Nina Rodrigues do Departamento de Polícia Técnica da Secretaria de Segurança Pública do Estado da Bahia, Salvador/BA.
5. Edwards (1997), Barringer; Flynn (1998), Arnoldi; Geary; Hardin (2001).

6. Lühning (1995-1996, p 218, nota 2).

7. Lühning (1995-1996, p. 201-211).

8. As instituições e coleções mencionadas no corpo do artigo aparecem, na primeira ocorrência, sob seu nome completo em itálico, sigla quando pertinente e sua localidade. As mais recorrentes são citadas depois pela sigla, ou, quando pertinente, por seu nome em redondo, o que também aplicamos nas legendas das figuras.

9. Sansi-Roca (2007) 
10. Schiffer (1972).

11. Hountondji (2008), Munanga (1983), Balandier (1976).

12. Meneses (1998), Pinheiro; Gonzalez de Gomez (2000), Smit (1987).

13. Mauss (1974).

14. Dantas (1988), Guimarães (2008).

15. Ribeiro Junior (2008, p. vi)
Outras dimensões desses objetos a considerar são as de natureza intrínseca ao seu processo de produção: são os recursos empregados na busca do material e em sua feitura; sua função técnico-utilitária, seus significados e os usos que thes são atribuídos; sua circulação, descarte e reúso. Esse modelo de análise, frequentemente empregado na arqueologia, ${ }^{10}$ pode ser adaptado nos estudos de objetos em coleções, especialmente as que comportam amostras da cultura material africana esterilizada, na África e no Brasil, nos processos de ruptura social durante o período de escravidão e colonização. Mas suas retomadas intermitentes, sob a dialética histórico-cultural instaurada nesse período, em ambos os lados do Atlântico, impõem que esses estudos se amparem também nas discussões epistemológicas dos estudos africanos e africanistas," tanto quanto de outras orientações transdisciplinares - da história às ciências da informação e à análise documentária. ${ }^{12}$

Esses objetos também fazem vezes de um saber prestigioso, interna e externamente ao contexto dos candomblés. Sua produção material e simbólica, consagrada e encoberta, passou a ser, com a introdução dos primeiros estudos etnológicos no Brasil, uma alegoria da etnicidade brasileira; ao mesmo tempo, como posse simbólica, sempre foram influentes na hierarquização de seus membros em face de disputas internas ao culto. Apesar de sua especificidade histórica e cultural, o poder emblemático dos objetos dos candomblés pode ser tratado sob a perspectiva estrutural e atemporal do clássico "Ensaio sobre a dádiva: forma e razão da troca nas sociedades arcaicas", 13 diante da complexidade do processo de troca e circulação de conhecimento entre dirigentes de culto, acadêmicos e a elite cultural nas primeiras décadas do século XX.14

As tensões entre a memória coletiva e o poder hegemônico, mediadas pelos valores culturais e históricos atribuídos por acumulação aos objetos dos antigos candomblés, fomentam, por si mesmas, programas de intervenção da gestão pública e de sua patrimonialização. Disso tratam muitos estudiosos de várias áreas do conhecimento. No campo dos candomblés, destacamos Ademir Ribeiro Junior, que recomenda, antes, a observância da compreensão do objeto em seu contexto sistêmico - do uso ao reúso, devemos considerar, em face do objeto, tudo o que, parodiando-o, "anima seu ciclo de vida". ${ }^{15}$

Diante da gama diversificada dos aspectos da cultura material dos candomblés, trataremos de um procedimento específico de análise - como todos, interdependente de outros -, que é a análise estilíistica. Sem que resulte apenas em uma interpretação formal do objeto, ela pode sublevar "mãos" das quais se originam certos objetos dos candomblés sob suas veladuras - sentidos e significados acumulados em sua história de vida até chegarem às delegacias e museus, onde, por sua vez, foram repincelados com novas camadas.

Reformulando o que destacamos de Angela Lühning, alguma inscrição, traços de feitura e outras características formais desses objetos fazem deles peças únicas. Mas resta que isso seja investigado e, ao ser feito, é preciso considerar, paradoxalmente, que - recortados da dinâmica de sua produção, nas coleções - foi sob a aura da singularidade material, técnica ou imagética que seu anonimato foi instaurado. 
16. Carneiro da Cunha (1983, p. 989-995).

A definição de arte afro-brasileira de Marianno Carneiro da Cunha, a partir do "elemento negro nas artes plásticas", 16 é precursora, ao mesmo tempo que vigente, mesmo considerando novas conceituações que vieram depois. ${ }^{17}$ Foi também sob abordagens das culturas e das sociedades africanas no tempo e no espaço que a expressão arte africana foi gerada, podendo explicar por que as formas antigas e contemporâneas das artes africanas e as tidas como originárias da África são, normalmente, compreendidas na sua pluralidade.

Marianno chamou a atenção para a individualidade dos artistas manifesta em fases e estilos dessa arte, ainda que muito depois da introdução desse tema nos estudos de arte africana. Foi quando Frans Olbrechts apresentou características comuns entre dez peças, duas dentre elas com origem precisa, coletadas em uma localidade chamada Buli, às margens do rio Lualaba, no sudeste da atual República Democrática do Congo (ex-Congo Belga e Zaire). Eram características compatíveis com a determinação de um subestilo da escultura conhecida como da periferia da "região estilística ba-luba". Olbrechts perfilou esse estilo escultural ainda em 19371938, quando da exposição "As artes do Congo Belga", nomeando-o como "de face alongada de buli". ${ }^{18}$ De perto, foi seguido por William Buller Fagg, quando este publicou peça similar do British Museum (Londres), em artigo intitulado "A Master Sculptor of the Eastern Congo" - trata-se daquele que passou a ser conhecido como "mestre de Buli". ${ }^{19}$ Seguem-se muitas outras investigações sobre estilos individuais da África central, ${ }^{20}$ bem como de outras regiões do continente. ${ }^{21}$

Essas pesquisas tiveram alcances importantes, mas limitados a estudos da identidade do artista em termos coletivos. $\bigcirc$ estilo de Buli parece ser uma excepcionalidade: François Neył chegou ao nome que poderia ser o de seu criador, Ngongo ya Chintu, que viveu nos anos 1830, segundo a tradição oral. ${ }^{22}$ $\bigcirc$ que se tira de análises e discussões sobre o método leva, mesmo nesse caso específico, à dúvida sobre ser o estilo buli de um único mestre, em vista de dados da história local refletidos em obras similares encontradas posteriormente. ${ }^{23} \mathrm{Com}$ isso, a grande maioria de artistas africanos e afro-brasileiros do passado permanece no anonimato, não bastando que atualmente venham a ser reconhecidos pelo ateliê que fundaram ou de que participaram.

A descolonização das ciências impôs, também aos estudos de arte africana, novos posicionamentos diante dos valores tradicionais dessa arte estabelecidos por uma clientela periférica ao seu contexto de produção. ${ }^{24}$ Mas os limites da sociedade, da arte e da cultura contemporânea e tradicional são fluidos, não podendo se atestar pureza estilística de formas artísticas, mesmo que delas se esperem originalidade e autenticidade. Nessa dualidade temporal híbrida e ambígua, colecionadores, junto dos especialistas de museu e outros acadêmicos das artes e das letras, estabelecem com os objetos uma relação de domínio, que a retomada dos estudos de cultura material no final da década de 1980, como vimos, critica e evidencia.
17. Munanga (2000), Salum (2000).

18. Olbrechts (1959, p. 7175).

19. Fagg (1948).

20. De Maret; Dery; Murdoch (1973), Neyt (1977).

21. Biebuyck (1969), D'Azevedo (1973).

22. Neyt (1977, p. 320-321).

23. Gossiaux (1990), Vogel (1993).

24. Steiner (1999), Kasfir (2008). 
25. Kamer (1974), Cornet (1975).

26. Price (2000).

27. Lody (2005).

28. Soares; Lima (2013), Bevilacqua; Silva (2015).

29. Coimbra; Martins; Duarte (1980).

30. Frota (2005)
No campo específico do nosso problema, pouco se diz de trabalhos já distantes que discutem a relativização da aparência física dos objetos, em favor de suas fontes de inspiração. ${ }^{25} \mathrm{E}$, com certa desolação, há que se dizer que o tema da autenticidade da arte não ocidental, em que sempre foram incluídos os objetos afroamericanos e afro-brasileiros, só se tornou pauta acadêmica entre nós com a tradução em português do consagrado ensaio de Sally Price, ${ }^{26}$ cuja primeira edição em inglês apareceu, mesmo assim, 11 anos antes. De fato, não temos visto até então, nos estudos sobre nossas coleções afro-brasileiras, uma reflexão sistemática acumulada que seja voltada à interpretação plena e possível desses objetos, exceto à forma pela qual passaram a ser tratados depois de confinados em museus e outras instituições, o que não é, porém, menos importante. Ressaltamos, com vistas nessa direção, os levantamentos resultantes do Projeto Estudos de Coleções Africanas e Afro-brasileiras, lançado em 1982 pela Funarte e coordenado por Raul Lody. ${ }^{27}$ Mas são raras as pesquisas que têm algo a nos ensinar sobre o estudo dos acervos africanos no Brasil e que vêm surgindo apenas nos últimos 15 anos. Entre elas, destacam-se a de Marta Rossetti Batista, sobre a Coleção Mário de Andrade, de 2004, e a já citada de Ribeiro Junior, de 2008, cabendo ainda lembrar as que vêm sendo introduzidas recentemente por Mariza de Carvalho Soares e Rachel Corrêa Lima, sobre a coleção A Africana do Museu Nacional, e, por Juliana Ribeiro da Silva Bevilacqua e Renato Araújo da Silva, sobre a do Museu Afro Brasil. ${ }^{28}$

Os fatores ideológicos, implicados na transmigração do objeto de culto ou de arte do contexto cultural de origem para o que o institucionaliza, fomentam uma confusão dialética entre autoria e anonimato e os criadores e proprietários dos objetos. $\bigcirc$ instrumental sob o qual os objetos são normalmente tratados nem sempre contempla todos os aspectos da cadeia operatória de uma produção artefatual, em que se inclui o "artista", um personagem que, até há pouco, tinha destaque apenas na historiografia da arte e nos estudos de cultura popular.

Há que se lembrar de $\mathrm{O}$ reinado da lua ${ }^{29}$ e Pequeno dicionário da arte do povo brasileiro, ${ }^{30}$ que não deixam de refletir, especialmente o dicionário, a orientação de alguns museus especializados no assunto, como o Museu do Folclore Edison Carneiro, do Centro Nacional de Folclore e Cultura Popular, e o Museu Casa do Pontal. Esses museus, situados na cidade do Rio de Janeiro, são especializados em arte popular brasileira, voltados à pesquisa da obra de artistas de mais de uma geração, ou individualizados pela sua inventividade, abrigando coleções procedentes de várias localidades e regiões do Brasil. A Casa do Pontal tem como orientação o trabalho de seu fundador, Jacques van de Beuque, que, pelo menos em visita técnica no final dos anos 1990, expressava-se no interesse pelos temas implicados nas relações tradição-modernidade do cotidiano, para além do imaginário popular, implicando o modo como as obras eram organizadas na exposição. Já o Museu do Folclore tem arraigada em si a orientação de Edison Carneiro, destacado estudioso do negro no Brasil, embora, também lá, pouco se veja, no tratamento do acervo, foco na herança africana e em sua descendência afro-brasileira. 
Havendo muito ainda a tratar dos artistas ou temas ligados ao segmento negro, cuja memória se resguarda, em parte, nas coleções específicas voltadas aos candomblés, vemos, do ponto de vista teórico, apoio nos novos estudos sobre a arte africana tradicional. A retomada desses estudos, que bem se configura na coletânea de trabalhos publicados em African culture material, ${ }^{31}$ se dá sobretudo a partir de grandes exposições formuladas a partir dos anos 1980, em particular da discussão que provocou a exposição "Primitivism' in 20th century art", realizada no Museum of Modern Art, em Nova York, em 1984. O que nelas se veicula passa a ser mais bem expressado, a nosso ver, com "Art/Artifact", exposição realizada em 1988 no Center for African Art, atual Africa Center, também em Nova York. Gerando obras de referência fundamentais, ${ }^{32}$ essas exposições despertam para o legado colonial africano cristalizado em ícones dessa arte recolhidos nos museus de caráter etnológico e que representam a pilhagem da África mais do que outra coisa. Essa pilhagem corresponde ao que ocorreu com a produção artística, técnica e estilística dos antigos candomblés de que aqui tratamos.

Diante disso, até que ponto a geração das coleções em museus não se sobrepõe ao problema da busca da autoria, da individualidade e da criatividade do artista? $\bigcirc$ anonimato, enquanto parâmetro para determinação de autenticidade das antiguidades ou das artes não ocidentais, não sucumbiu mesmo quando da primeira proposta de metodologia sistemática aplicada aos estudos de objetos e da cultura material, já quase engolida pelo tempo, não fosse sua singularidade na época. Em Method of Studying Ethnological Art, de 1961, Herta Haselberger já apontava a investigação do papel do artista na sociedade e de seu histórico como condição fundamental para a compreensão da obra.

A determinação de autoria é um tema que ressurge nos anos 1990, em função das obras de arte, e não dos artistas - estes sempre bem conhecidos pelos colecionadores, estudiosos e agentes de museu, como se depreende do artigo de Susan Vogel "Known Artists but Anonymous Works", em cujo título nos inspiramos para nomear o presente item deste artigo. ${ }^{33}$ Henri Kamer, em De authenticité des sculptures africaines, começa por tocar no preço que as esculturas africanas atingiram a partir do pós-guerra com anuência de acadêmicos comprometidos com a obscuridade de sua origem e autoria. ${ }^{34}$ Poucos são os trabalhos que, como o desse expert internacional no campo das artes, revelaram estilos autorais da arte africana cuja designação foi omitida no processo de formação das coleções.

A autoria da arte africana é tema que passou a ser imposto às avessas. Os estilos de chefs d'oeuvres passaram a ser mais amplamente estudados e, em 2001, deu-se a exposição intitulada "Mains de Maitres: a la découverte des sculpteurs d'Afrique", realizada no Espace Culturel BBL, em Bruxelas, e organizada por Bernard de Grunne. A noção de estilo individual passa, então, a identificar obras de grandes artistas, mas com interesses outros, já que são "mãos de artista" reveladas a partir e em função do próprio mercado de arte africana internacional, que um dia as refutou. E isso continua a ser feito por alguns dos especialistas desse grande e restrito fórum de colecionadores, que são também acadêmicos - basta
31. Arnoldi; Geary; Hardin (1996)

32. Rubin (1984), Danto et al. (1988).

33. Vogel (1999).

34. Kamer (1974, p. 36). 
35. Walker (1994).

36. Fagg (1969), Abiodun; Drewal; Pemberton II (1994).

37. Barata (1957, p. 55-56).

38. Rodrigues (1935, p. 162).

39. Ipeafro (2015).

40. Verger (1968, 1986, 1999). consultar os catálogos da mais prestigiosa casa de leilões do mundo, a Sotheby's, para lá identificá-los.

Estilos e mãos de artista "gêge-nagô" e iorubanos: registro de um campo de estudos

Seria bom se sempre fosse possível dizer: "anônimos têm um nome", como no tífulo de um artigo de Roslyn Adele Walker sobre um escultor iorubano falecido em 1938, "Anonymous has a name: Olowe of Ise". ${ }^{35} \mathrm{~A}$ fama da escultura de Olowe iá corria a Nigéria quando a peça foi fotografada por um etnógrafo a serviço do National Museum na passagem entre os anos 1930 e 1940. Olowe of Ise era um "artista de corte" a serviço do rei de Ise (Estado de Ekiti, Nigéria), mas trabalhou sob encomenda para vários outros governantes e famílias abastadas de outras localidades do território iorubano. Um dos primeiros especialistas a publicar sobre esse artista, e sobre outras mãos de artista do fim do século XIX e início do século XX, foi também William Fagg, mas ele apenas encabeça uma vasta bibliografia de pesquisas disponíveis sobre a identidade do artista e estilos artísticos iorubanos, dados em extenso período de tempo. ${ }^{36}$

Esses estudos sobre o artista iorubano, como os de outras sociedades africanas referidos no item precedente, nos indicam como são complexas as possibilidades de aproximação da escultura brasileira com a africana, sendo discutível a identificação formal das antigas esculturas dos candomblés, pelo menos em sua totalidade e referindo-nos às mais difundidas, com a arte dos iorubás e de outras culturas do Golfo do Benim, apontadas desde Nina Rodrigues.

Referindo-se à formação de um "centro de escultura ligado à manutenção dos cultos negros", Mario Barata ${ }^{37}$ já havia assinalado a possibilidade de haver tido importação de esculturas africanas quando do comércio marítimo entre a Bahia e Lagos durante o século XIX, que Nina Rodrigues havia anunciado. ${ }^{38}$ Barata destacava a importância da diferenciação entre peças que teriam sido trazidas da África e as feitas aqui por africanos e seus descendentes. Diz Abdias do Nascimento que foram os estudos de Mário Barata que, ainda em 1950, o levaram a decisão de organizar o Museu de Arte Negra no Rio de Janeiro. ${ }^{39}$

Vem da mesma época Pierre Verger, que ampliou a abordagem histórica das relações culturais Brasil-África que já vinha sendo aplicada na etnologia brasileira sobre o negro. ${ }^{40}$ Mas, ainda que de extrema relevância, sua produção impôs uma orientação, que deveria ser repensada, sobre a identidade entre a cultura material africana e brasileira na curadoria adotada por museus brasileiros. Entre os museus universitários no país que têm acervos atinentes aos temas africanistas estão o Museu Afro-brasileiro da Universidade Federal da Bahia (Mafro/UFBA), em Salvador/BA, e o Museu de Arqueologia e Etnologia da Universidade de São Paulo (MAE/USP), em São Paulo/SP, a que se junta, de certo modo, o Museu Afro Brasil (MAB), também em São Paulo/SP, por desenvolver pesquisa acadêmica intensiva em função do público escolar de grande importância que atende. 
A relação das culturas dos povos do Golfo do Benim com as populações da Bahia e do Nordeste brasileiro tem sido tema dos programas de extensão e difusão do conhecimento desses três museus. No caso do acervo do MAE/USP, essa relação ganha visibilidade destacada pela própria constituição das coleções africanas originárias, em maioria, dessa região do continente, pelas mãos de Marianno Carneiro da Cunha - Marianno manteve, no período, trocas acadêmicas e amizade com Pierre Verger, ${ }^{41}$ podendo-se dizer o mesmo em relação à constituição das coleções do Mafro/UFBA.

Essa é a razão pela qual, no passado, a exposição permanente do MAE/USP, montada no bloco D do Conjunto Residencial da Universidade de São Paulo (Crusp), era uma espécie de reserva técnica visitável, podendo despertar para uma estranha simbiose entre a África e o Brasil. ${ }^{42} \bigcirc$ mesmo poderia ser dito da sala de arte africana do MAB, também em São Paulo, onde a relação do candomblé com a arte iorubana e nigeriana fica evidenciada, embora os objetos de culto do acervo em si mesmos, em sua maioria inspirados na produção nagôiorubana, ocupem ala separada, ainda que contígua. ${ }^{43}$

Mas nem sempre é possível estabelecer uma relação concreta e formal entre os objetos dos candomblés antigos e os de estilos africanos compreendidos nessa grande área do território africano, que é de onde viriam os elementos "gêgenagô" da cultura brasileira. Os estudos consolidados sobre estilos artísticos dos iorubás, a que nos referimos acima, e os estudos sobre as chamadas "artes tradicionais" da África pouco foram cultivados entre nós, no Brasil, até pouco tempo atrás, embora, sob seu pretexto, tenha havido intensa troca entre estudiosos do negro no Brasil nos anos 1930 e 1940 e pesquisadores estrangeiros, como se vê nos arquivos e na correspondência de Arthur Ramos. ${ }^{44}$

Devemos considerar também que não há ainda trabalhos-síntese sobre estilos "iêje" conhecidos, a não ser African Vodun, de Susan Preston Blier, que inclui um apêndice sobre "coleções e características estilísticas". Nessa publicação, ressalta-se a dificuldade de atribuição de estilo à escultura de bocio (bochio, botchio ou "botiô") dada ao movimento de povos e objetos nessa região do continente no curso dos últimos séculos. ${ }^{45} \mathrm{Na}$ descrição pormenorizada dos estilos das 11 áreas culturais do Benim e do Togo, identificados através do vasto corpus de objetos que pesquisou Suzanne Blier, veem-se alguns elementos já estabelecidos antes como nagô-iorubanos na literatura acima mencionada, mas que não se configura m como determinantes da área, não havendo chaves de classificação suficientemente claras de distinção formal no próprio território africano, quanto mais para uso comparativo com produções brasileiras - estas mesmas pouco estudadas com rigor. A leitura de Dahomey: an ancient West African kingdom, de Melville Herskovits, um dos mais eminentes africanistas representantes da antropologia cultural e que se debruçou sobre a arte, não respondeu à busca. ${ }^{46}$

Prosseguir na tendência de considerar a herança iorubana como predominante na inspiração artística brasileira, tanto quando vinha sendo feito nos estudos sobre a religiosidade, vai contra uma aproximação controlada, se é que
41. Matos (2012, p. 58-63), Salum (1999), Barcelos Neto et al. (2007, p. 812-822).

42. Salum; Ceravolo (1993).

43. Salum; Bevilacqua (2011).

44. BNdigital (2014); Faillace (2004).

45. Blier (1995, p. 355-359).

46. Herskovits (1938) 
47. Zanini (1983).

48. Silva (2004).

49. Salum (1999), Salum; Ceravolo (1993), Silva (2004), Matos (2012). ela pudesse ser feita de fato, entre antigos objetos dos candomblés e as artes da África propriamente ditas.

De qualquer modo, não fosse por sua morte prematura, é provável que Marianno Carneiro da Cunha tivesse chegado lá a partir do que ele deixou. Marianno Carneiro da Cunha deixou no MAE/USP coleções de grande valor pedagógico, voltadas à identidade entre as artes africanas e brasileira, enaltecendo a porção na história que ocupam o Brasil e a África, porém sem declinar das especificidades do estudo de suas produções artísticas e da estilística diferenciada em que se dão desde o passado. Tomou essas coleções como referência, o que resultou no capítulo sobre arte afro-brasileira de sua autoria, impensado em uma história geral da arte no Brasil antes da que organizou e coordenou o professor Walter Zanini. ${ }^{47}$

Marianno nos trouxe uma articulação do conhecimento acumulado até então em arqueologia africana, etnologia africana no Brasil e história da África com os estudos de cultura material. "Mãos de artistas iorubanos", tema de importância na época, como demonstra a bibliografia apontada acima, veem-se lá representadas, mas dentro de uma perspectiva brasileira. Introduziu, no Brasil, elementos para o estudo de coleções em museus que documentam um estado da questão das disciplinas voltadas à pesquisa de objeto ainda hoje atual - seja objeto de candomblé, seja objeto de "arte africana", no sentido mesmo com que a expressão foi enunciada no início do item anterior deste artigo.

Mas a correspondência institucional de Ulpiano Bezerra de Meneses e Marianno Carneiro da Cunha, empenhados na constituição de coleção africana do MAE/USP entre 1969 e 1974, já indicava também o acervo do MAE/USP como um projeto acadêmico que envolvia personalidades da época que constituíam o staff internacional que alinhavava a arte africana, já de então consagrada como patrimônio universal pela Unesco, com os estudos africanistas no Brasil e as relações do Itamaraty com os novos países africanos logo depois da libertação colonial. Num outro plano, vê-se aqui uma continuidade do que houvera acontecido entre intelectuais brasileiros e americanos interessados nos objetos extraídos dos candomblés décadas antes, como já nos referimos, que se dava agora também com colecionadores, empresários e diplomatas, e não apenas acadêmicos, como se revela no levantamento e estudo da documentação escrita do acervo desse museu. ${ }^{48}$

Em vista da formação dos museus da Nigéria ocorrida em 1957, até o fim da década de 1970, quando já se tinha dado forma pretendida ao acervo africano no MAE/USP e quando, em Salvador, a fundação do Mafro/UFBA estava sendo consolidada, essa documentação acusa a influência nesse processo de nomes que vão de Pierre Verger a Ekpo Eyo, que dirigiv o Departamento Federal de Antiguidades da Nigéria entre 1967 e 1979.49

Dentro dessa problemática é que retomamos, para finalizar este item, duas esculturas chamadas de "estátuas de iemaniá", presentes nas exposições permanentes do MAE/USP (década de 1980) e do Mafro/UFBA (década de 1990). Esta, de $47 \mathrm{~cm}$, com marcas de uso ou manuseio, mas também preenchimentos de restauro, 
parece ter servido de inspiração à estátua exposta no MAE/USP, de $64 \mathrm{~cm}$, tendo a superfície apenas selada. Têm diferenças no tratamento dado a certos traços da figura humana que representam - nem tanto no formato do rosto, nas mãos "em pinça", na extensão da fronte e no contorno da cavidade ocular e pálpebras, semelhantes nas duas -, mas são constituídas dos mesmos elementos e proporções que formam o todo, no que são extremamente parecidas.

A estátua do acervo do MAE/USP foi encomendada por iniciativa de Pierre Verger a um artesão baiano, em resposta ao pedido de auxílio do MAE/ USP na obtenção de material afro-brasileiro para permuta de coleções africanas com instituições estrangeiras - permuta lograda, e por isso ela foi incorporada a seu acervo. ${ }^{50}$

Já a estátua exposta no Mafro/UFBA tem sido difundida através de Orixás: deuses africanos na África e no Novo Mundo como expressão, no Brasil, de verossimilhança com esculturas africanas, ${ }^{51}$ sem que vejamos semelhança formal nem estilística no exemplo dado pelo autor.

Contudo, podemos dizer que essa estátua do Mafro/UFBA é extremamente semelhante ao "trono ou banco esculpido do culto de iemanjá", de 60 cm, publicado por Nina Rodrigues em 1904 (Figura 2). ${ }^{52}$

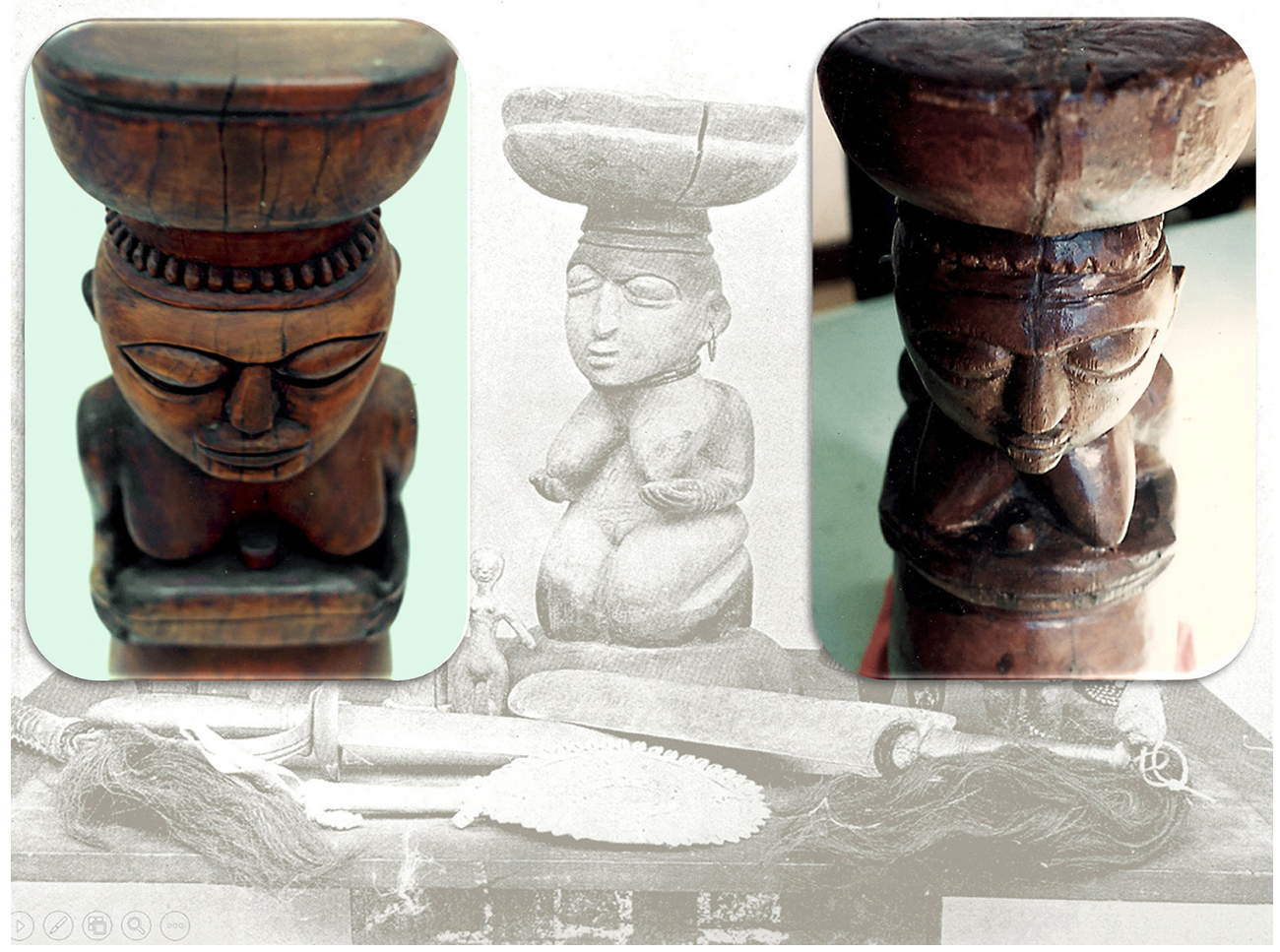

Figura 2 - Estátuas conservadas no Museu de Arqueologia e Etnologia da USP, São Paulo/SP, em fotografia da autora (c. 1999), à esquerda (Acervo MAE/USP 74/2.6), e, no Museu Afro-brasileiro da Universidade Federal da Bahia, Salvador/BA, em fotografia da autora (c. 1998), à direita (Acervo MAFRO/UFBA E/NEL 136), sobrepostas à de Nina Rodrigues vista na Figura 1.
50. Salum (1999, p. 174178).

51. Verger (1986, p. 197, fig. 167).

52. Sobre as figuras de ilustração e créditos: com exceção da Figura1, as figuras aqui apresentadas são compostas pela autora e expressam interpretações resultantes do levantamento de peças em coleções que vem realizando. Elas deram origem ao texto deste artigo, mas podem também servir a sua melhor compreensão. São compostas, em maioria, de fotografias extraídas de publicações cujas referências bibliográficas vão indicadas nas legendas, tomadas em detalhe ou recorte dos originais tratados graficamente pela autora. A estas se somam fotografias tomadas de peças do acervo do MAE/USP e de outras coleções que a autora veio estudando presencialmente desde 1995, com anuência das instituições responsáveis, desde já, aqui destacadas: Museu Afro-Brasileiro da Universidade Federal da Bahia, Museu Nacional da Universidade Federal do Rio de Janeiro, Instituto de Estudos Brasileiros da Universidade de São Paulo e Museu Afro Brasil. 
53. Carneiro da Cunha (1983).

54. Carneiro da Cunha (1983, p. 996, 999-1.003).
É como se essas estátuas, que também são bancos, repartissem a tarefa de rememorar aquela peça única e primeva. Desde Nina Rodrigues até as pesquisas em andamento, não se viu mais nada igual. Excedem as dimensões das estatuetas conhecidas, não apenas desse estilo mas também de mesmo gênero, e não têm as funções mobiliárias e arquitetônicas que elas poderiam ter tido.

A estátua do MAE/USP, por sua vez, passa a ser muito mais do que ela poderia representar em uma vitrine. Ela é uma representação alusiva a Pierre Verger e a Nina Rodrigues. E nos coloca diante do anonimato conferido aos artistas que criaram as obras de que aqui estamos tratando.

Não seria improvável encontrarmos outras esculturas similares a esses objetos mais antigos ainda existentes que, sendo tiradas do contexto do culto, ou sendo simples cópias, serão sempre alusivas às primeiras produções acadêmicas sobre o negro no Brasil ou a representação dos candomblés por eles veiculada. Não é por acaso que se incorre na possibilidade de chamar um objeto através do terreiro de onde foi tirado, do nome da instituição onde ele se conserva e mesmo do pesquisador que o estuda e o revela, desempenhando, às vezes, o papel de seus colecionadores e gestores.

Embora fosse, de algum modo, pertinente, Marianno não mencionou a estátua de iemaniá do acervo do MAE/USP em seus estudos estilísticos. Mesmo sendo uma cópia, fica ela, de nossa parte, já incluída antecipadamente no corpus que formamos a partir da seleção de peças de "tradição nagô-iorubana" referidas no texto do autor, que passaremos agora a analisar.

Um ateliê baiano que outros compreende, ou dos protótipos e das cópias

Além da familiarização que parecia já ter com os cultos, Marianno Carneiro da Cunha estava familiarizado também com os crescentes estudos estilísticos da arte iorubana. Como os estudiosos de seu tempo, interessava-se pelo componente nagô-iorubano nas culturas nas Américas e nos candomblés. Foi daí que tentou estabelecer o que chamou de "evolução formal e iconográfica" da escultura africana no Brasil, identificando aspectos morfológico-estilísticos daquela arte em exemplares conhecidos de "escultura de madeira em relevo completo". Isso ocupou parte importante de suas pesquisas, resumidas em Arte afro-brasileira. ${ }^{53}$

Marianno começou por fazer algo ainda impensado: elencou as coleções mais antigas oriundas dos cultos afro-brasileiros, de onde selecionou as esculturas que analisou. Dentre as características comuns aos exemplares de sua amostragem e seus correspondentes africanos, o autor aponta a distribuição equilibrada das formas da figura humana (seios e nádegas) em torno de um eixo vertical "como na África", mas de nariz aquilino, boca, formato dos seios e volume da cabeça, proporcional ao corpo, mais próximos dos "padrões estéticos brancos". Complementa: "Os olhos saltados em forma de grão de café seguem, entretanto, a tradição nagô-yorubá". ${ }^{54}$ 
A partir de sua análise, Marianno sugere a existência de um "atelier baiano" antes ainda não perfilado, "de grande renome e que deve ter perdurado até a década de 1930", 55 referindo-se provavelmente à suposta esterilização da produção de objetos de uso ritual devido ao recrudescimento da perseguição policial contra os candomblés no período. $\bigcirc$ texto de Marianno é póstumo, sobre o qual ele ainda trabalhava dias antes de falecer, como diz, em nota introdutória, Walter Zanini, coordenador da obra, tendo sido publicado três anos depois de sua morte. ${ }^{56}$ Diante do estado atual da questão, parece restar muito a ser esclarecido, referenciado e ilustrado, sem deixar de considerar seu pioneirismo em reunir uma documentação então dispersa e inédita na abordagem do tema. Refazendo o percurso de Marianno, passaremos à apresentação dos objetos que tomou por referência, analisando-os agora entre si. Eles são explicitados no seguinte trecho do texto do autor:

\begin{abstract}
A mesma tradição escultórica apresentada pelas peças referidas [tratava-se de três objetos da coleção do Instituto Geográfico e Histórico da Bahia (IGHBA), Salvador/BA] está também presente na Yemanjá e num beji (ibeji) do Museu Estácio de Lima, num oxê Xangô baiano, do Museu do Instituto de Estudos Brasileiros, e num par de ibeji analisado por A. Ramos. Trata-se muito provavelmente de atelier baiano, de grande renome e que deve ter perdurado até a década de 1930.57
\end{abstract}

Somam sete objetos, entre eles duas estatuetas que podem ser consideradas como parte de um único objeto (o "par de ibeji analisado por Arthur Ramos"). Pelo que se tem da escultura iorubana, postura e disposição dos braços ou elementos emblemáticos junto ao corpo nem sempre devem ser considerados como aspectos estilísticos individuais, embora possam indicar categorias diferentes da estatuária. Assim, um oxê sempre haverá de apresentar a forma do machado duplo que o simboliza e ao mesmo tempo o consagra, ou os braços de um ibeji vão estar paralelos ao corpo, enquanto os dos oxês, flexionados e vertidos à barriga ou ao peito. Suas dimensões correspondem às da arte iorubana: os oxês medem entre $40 \mathrm{~cm}$ e $65 \mathrm{~cm}$, e os ibejis, entre $20 \mathrm{~cm}$ e $35 \mathrm{~cm}$, sem muito exceder essas faixas, mas, no texto de Marianno, não se vê abordagem da variabilidade das dimensões das peças, o que evitaremos também aqui, embora cabível oportunamente.

Todas essas peças podem ser consideradas como figuras humanas esculpidas isoladas no espaço, ou a tutto-tondo. É natural que assim sejam consideradas as estatuetas de "ibeji" e a de "iemanjá", mas cabe considerar que os "oxês de xangô", ainda que normalmente embasados por uma empunhadura, também são, embora tenham perfil mais afilado e menos detalhamento de baixorelevo nas laterais. É isso que se depreende do que Marianno tratou como "escultura de madeira em relevo completo". ${ }^{58}$

Comecemos pela estátua chamada "Yemaniá". Marianno aponta essa estátua como pertencente ao Museu Estácio de Lima. Assim também acusava a documentação do Mafro/UFBA, quando lá em comodato, e a fotografamos: tratase da estátua a que já nos referimos há pouco, vista na Figura 2 (à direita).
55. Carneiro da Cunha (1983, p. 1.000)

56. Carneiro da Cunha (1983, p. 974).

57. Carneiro da Cunha (1983, p. 1.000).

58. Carneiro da Cunha (1983, p. 999). 
59. Tavares; Verger (2013, p. $52,56)$.

60. Carneiro da Cunha (1983, p. 996).

61. Thompson (1993, p. 150-151)
Sua fotografia aparece em um texto de Odorico Tavares publicado pela revista $O$ Cruzeiro de 14 de abril de 1951, junto com as de outras quatro peças fotografadas por Pierre Verger atribuídas, "com exceção de duas", à "coleção do Instituto Histórico". ${ }^{59}$ Certamente Odorico se referia ao Instituto Geográfico e Histórico da Bahia (IGHBA), em Salvador, onde também eram receptados objetos apreendidos nos candomblés da Bahia no passado.

Tivemos acesso ao artigo apenas por essa reedição, que não acusa seus dados cadastrais, senão a legenda "Arte afro-brasileira - Salvador BA - 19461950", o que indica, pelo menos, o período provável em que Pierre Verger a fotografou. São lacunas da documentação de peças nos museus e outras instituições transportadas às publicações, a serem preenchidas. Mas Marianno informa que parte do acervo do IGHBA, proveniente do candomblé de Pulquéria, Gantois, estava, em sua época, no Museu Estácio de Lima, ${ }^{60}$ e a originalidade dessa "Yemaniá" parece indiscutivel.

Em Face of Gods: Art and Altars of Africa and the African American, essa estátua veio a ser tema de interesse também de Robert Farris Thompson, que a publica sob o nome de "Yoruba Seat for Shango", através de uma fotografia tomada por ele em 1984 no Mafro/UFBA. Toma-a como ilustração do olhar exorbitante, um sinal que atribui à presença dos deuses manifestada nas pessoas em estado de possessão, que "ecoa na escultura, desde os olhos abaulados vistos em muitas formas de arte dos iorubás na Nigéria até um dos monumentos da arte de altar iorubano no Novo Mundo". ${ }^{11}$ Tanto no texto quanto na legenda, a troca de identidade dessa "Yemaniá" com a do "trono" de Nina Rodrigues parece evidente (Figura 3).

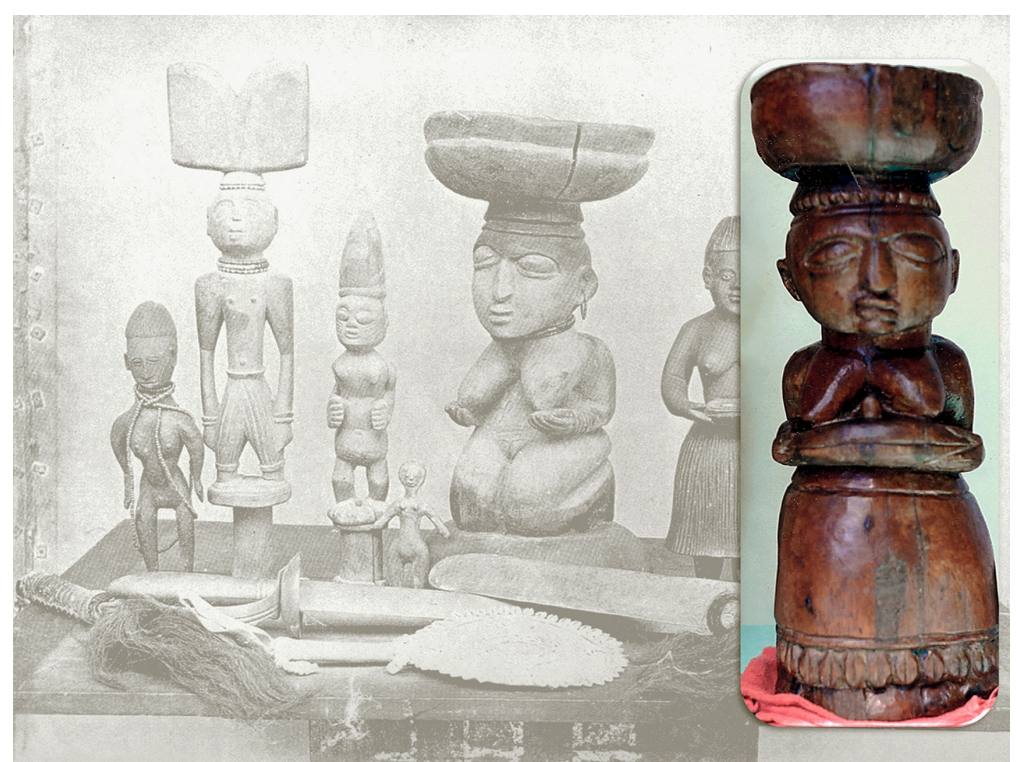

Figura 3 - A "Yemaniá", como referida por Marianno Carneiro da Cunha, em fotografia da autora (c. 1998), no Museu Afro-brasileiro da Universidade Federal da Bahia, Salvador/BA (Acervo MAFRO/UFBA E/NEL 136), sobreposta à fotografia publicada por Nina Rodrigues vista na Figura 1. 
Suas mãos em pinça, sustentando uma gamela, são as mesmas da estatueta de oxum (na fotografia, entre ela e o "trono"), e vê-se em ambas a saia armadinha que veste seus quadris arredondados. Marianno não se refere a isso, tampouco a sua semelhança com esse "trono ou banco de iemanjá" publicado por Nina, talvez por ter balizado suas análises de estilo sobre objetos dos antigos candomblés em coleções. Essa peça da fotografia de Nina Rodrigues nunca mais foi vista, podendo ter sido consumida, junto das demais peças inflamáveis lá retratadas, no incêndio do prédio da Faculdade de Medicina da Bahia, um ano depois de sua publicação. ${ }^{62}$ Mas é bom investir na busca de peças antigas desaparecidas, pois foi o que aconteceu, justamente, com outra peça de latão que integrava o conjunto analisado por Nina Rodrigues - se não for réplica idêntica, o que seria pouco provável, o "bastão de régulo africano" reapareceu na coleção do artista Carybé herdada por sua família, em Salvador. ${ }^{63}$

Não foram incluídas na publicação de Marianno ilustrações de todas as peças que selecionou para discernir esse estilo nagô-iorubano, como a do "par de ibeji analisado por Arthur Ramos" e a do "oxê xangô baiano do Museu do Instituto de Estudos Brasileiros" (Figura 4).

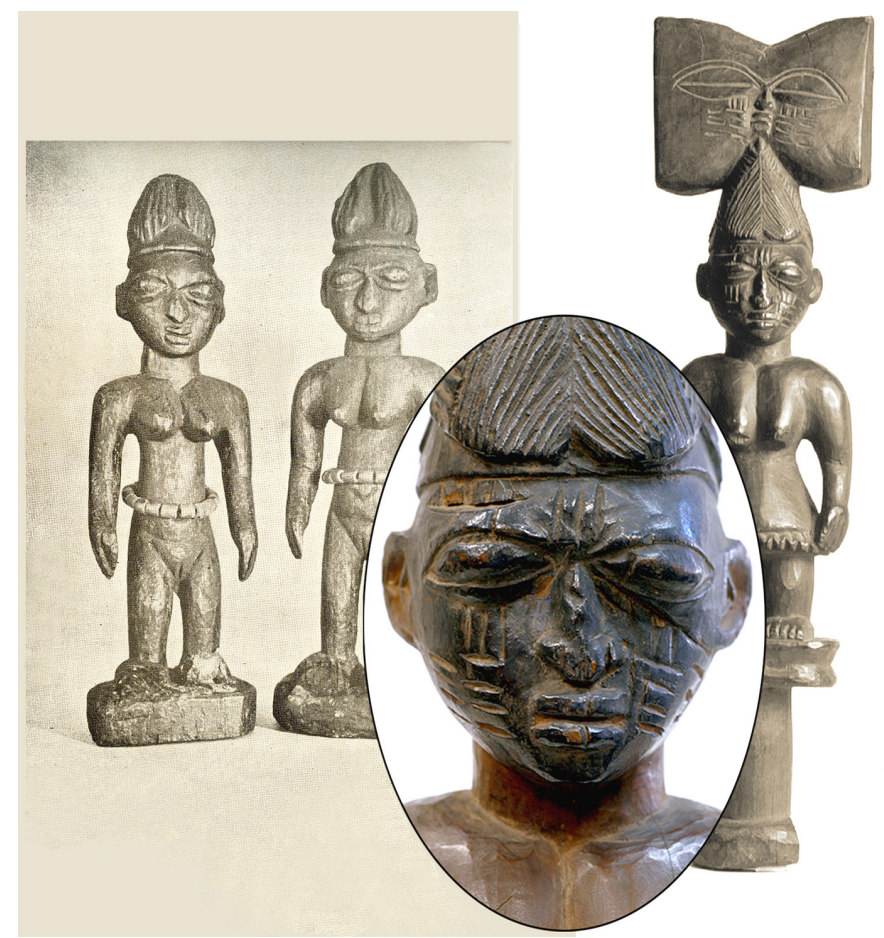

Figura 4 - "Oxê de Xangô" (Acervo IEB/USP MA-0751) do Instituto de Estudos Brasileiros da Universidade de São Paulo, São Paulo/SP (Col. MA - Col. de Artes Visuais), tomada integral à direita da figura, em fotografia de Romulo Fialdini publicada por Marta Rossetti Batista (2004, p. 236, peça n. 751); em detalhe, fotografia de Wagner Souza e Silva tomada em 2004 em colaboração com a autora. Vão compostas ao lado e sobre a fotografia do par de ibeji da Casa José de Alencar da Universidade Federal do Ceará, Fortaleza/CE (Coleção Arthur Ramos), conforme publicado por Ramos (1949, fig. III, entre p. 198 e p. 199).
62. Ribeiro Junior (2008, p. 126).

63. Ribeiro Junior (2008, p. 126-131). 
64. Ramos (1949, p. 202).

65. Batista (2004, p. 236).

66. Batista (2004, p. 40-42, 236).

67. Ramos (1934, p. 34-35).

68. Batista (2004, p. 42).

69. Barata (1957, p. 55).

70. Thompson (1984, p. 88, plate 53).
O par de ibeji se situa hoje na Casa José de Alencar da Universidade Federal do Ceará, em Fortaleza/CE (Coleção Arthur Ramos). Já o oxê permanece no Instituto de Estudos Brasileiros da Universidade de São Paulo (IEB/USP), em São Paulo/SP, como parte de sua Coleção de Artes Visuais, que integra peças da coleção particular de Mário de Andrade. São mesmo visíveis as semelhanças entre ambos os objetos, sobretudo no que diz respeito ao tronco e à cabeça da figura humana que representam. Esse par de ibeji foi colhido, como se lê nas palavras de Arthur Ramos, "nos candomblés da Bahia em 1927, mas não conseguimos apurar a data de sua feitura". 64

Quanto ao oxê de figuração similar do IEB, Marta Rossetti manteve-se prudente, declarando seus dados de coleta e procedência "desconhecidos", ${ }^{65}$ mas veio a considerar sua procedência baiana. Um documento que analisou, datado de 1936, poderia testemunhar que esse oxê tivesse sido uma encomenda particular de compra de objetos na Bahia feita por Mário de Andrade, referindo-se também à correspondência que ele trocou com Arthur Ramos desde 1933. A partir da pesquisa de Marta Rossetti, sabe-se, também, que há nos arquivos de Mário de Andrade, no IEB/USP, fotografias de peças da coleção do escritor, estando entre elas a deste par de ibeji, advinda da correspondência havida entre ambos. ${ }^{60}$ De fato, parece ser ela um detalhe omitido da fotografia publicada como Figura 6 em Ramos. ${ }^{67}$

Não se pode descartar a intermediação de Arthur Ramos na feitura desse oxê, sobretudo diante da menção, nessa correspondência, do secretário do \|l Congresso Afro-brasileiro, que respondia, junto a um pai de santo, por um orçamento que Mário de Andrade houvera feito, através de carta de um dos organizadores do congresso, Aidano do Couto Ferraz, datada de 13 de outubro de $1936 .{ }^{68}$

À "Yemaniá do Museu Estácio de Lima", ao "par de ibeji analisado por Arthur Ramos" e ao "oxê xangô baiano do Museu do Instituto de Estudos Brasileiros" juntamos agora os três oxês do IGHBA pelos quais Marianno começou a enunciar a tradição escultórica que estipulou (Figura 5).

Um desses três oxês selecionados por Marianno (o da direita) foi publicado por Mario Barata como sendo "Figura de lemaniá, pertencente a coleção baiana, proveniente de antigo candomblé local".69

O vestido com uma saia e mãos no ventre de um lado e de outro lo da esquerda) foi também publicado por Thompson. ${ }^{70}$ É com esse oxê que podem ser relacionados dois interessantes exemplares: de um lado, o do acervo do Museu Nacional da Universidade Federal do Rio de Janeiro (MN/UFRJ), Rio de Janeiro/RJ, e, de outro, o conservado no Museu Afro Brasil (MAB), São Paulo/SP (Figura 6).

São de figuras ajoelhadas. Duas apresentam as mãos segurando, de um lado e de outro, a sua barriga inflada e seios de formato semelhante, enquanto se veem, no oxê do $M A B$, mãos em concha, com as palmas voltadas para cima, como a iemanjá do trono de Nina Rodrigues à base dos seios. Nesse aspecto, também lembra a "Yemanjá" considerada por Marianno, vista na Figura 3 comparada ao trono de Nina: nessas duas peças, como no oxê do MAB, os seios 


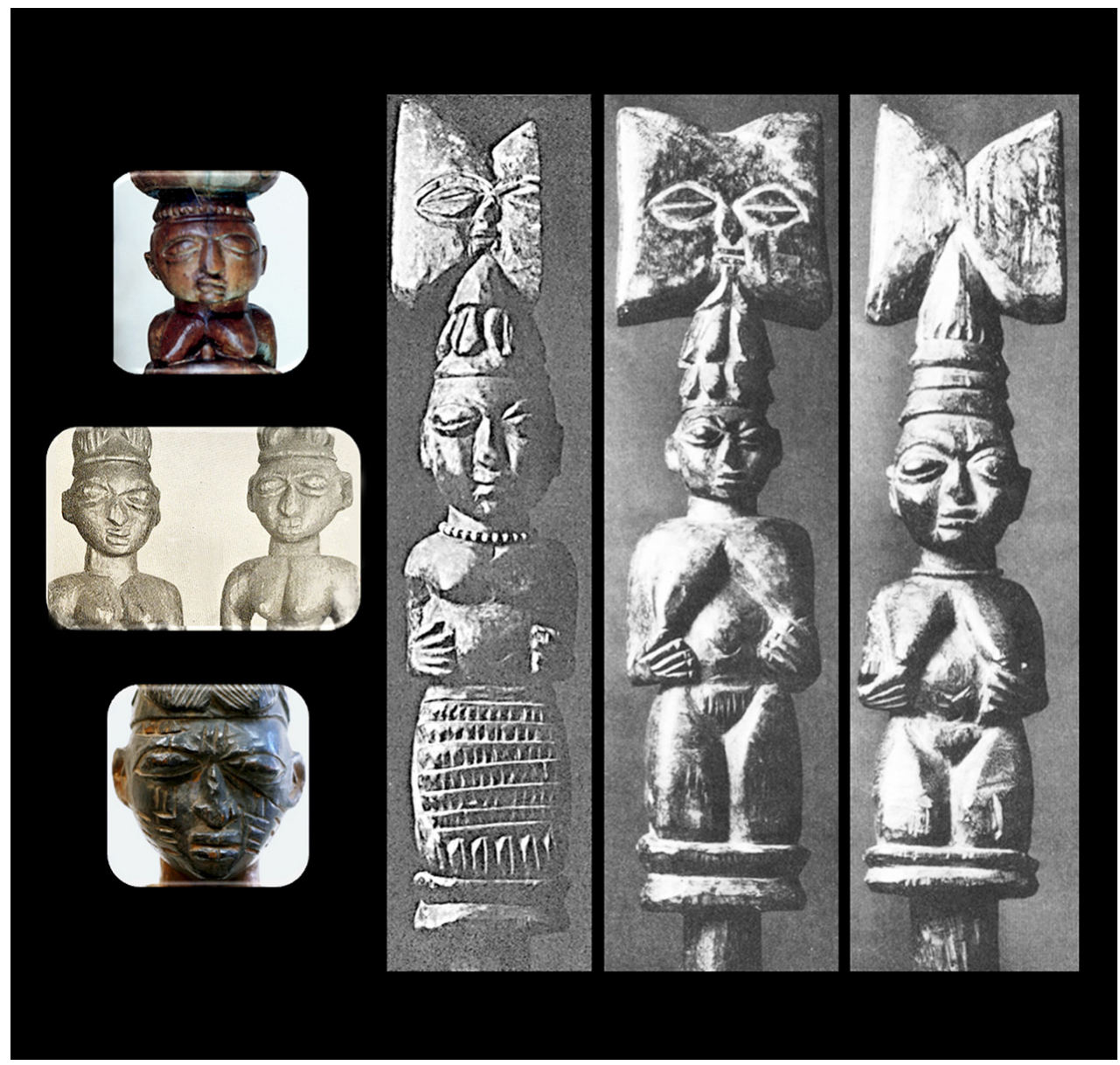

71. Soares; Lima (2013, p. 341, n. 5-7).

Figura 5 - Oxês do Instituto Geográfico e Histórico da Bahia, Salvador/BA, em fotografias de Romulo Fialdini, conforme publicados em Carneiro da Cunha 11983, p. 999, fig. 1366, 1367 e 1378), junto dos três objetos de sua seriação, já vistos nas Figuras 3 e 4.

da figura humana esculpida recaem sob forma de dois afilados, mas como que inflados, cones arredondados divergentes, já a partir da base do pescoço.

Nos três oxês destacados nessa figura, consta uma saia texturizada e embarrada de cauri. $\bigcirc$ oxê do MAB não apresenta uma espécie de cabeleira em forma de coroa definida nesses seus pares do IGHBA e do MN/UFRJ, mas ela pode estar dissimulada por suas feituras desgastadas, não se sabe se por ação do tempo, abandono ou tentativa de destruição. Ele não tem dados de proveniência.

oxê do Museu Nacional, por seu lado, tem como número de entrada na instituição o 37.478, o que indicaria ser de data posterior à dos lotes de peças baianas que Heloísa Alberto Torres, enquanto diretora, coletou nas três viagens que fez à Bahia, em 1940, 1950 e 1953.71 De acordo com o livro de registros do Setor de Etnologia e Etnografia, tem-se que esse último lote foi trazido em março de 1953 e vai do número 35.797 a 35.842. Poderia ser do segundo, de três anos antes, mas do primeiro seria improvável, pois coincide com o período em que 
72. Côrrea; Mello (2008, p. 18, n. 17).
Heloísa providenciou em Salvador a feitura das bonecas de baianas destinadas a representar o Brasil na Exposição Histórica do Mundo Português de 1940, representação que não ocorreu. ${ }^{72}$

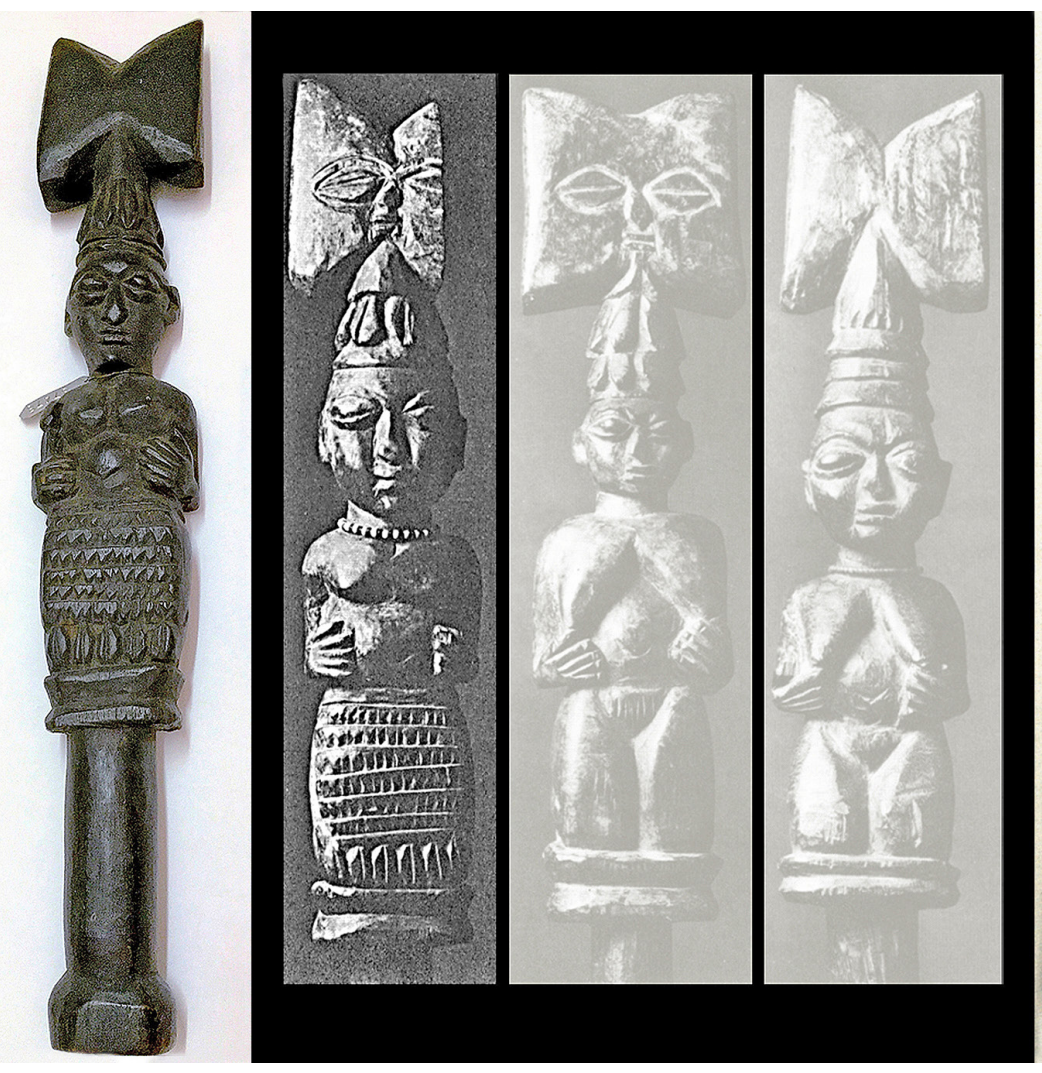

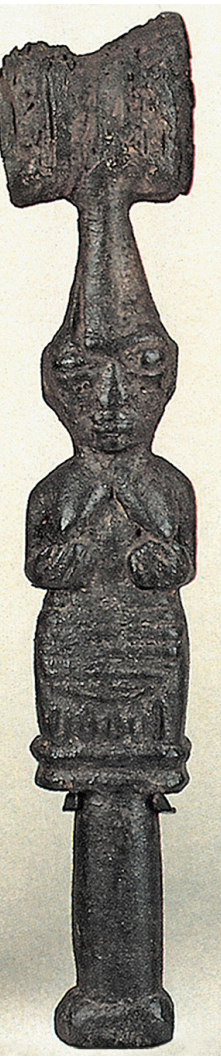

Figura 6 - Da esquerda para a direita: oxês do acervo do Museu Nacional do Rio de Janeiro, Rio de Janeiro/RJ, com fotografia da autora, c. 2013 (Acervo do Setor de Etnologia do MN/UFRJ 37478); Instituto Geográfico e Histórico da Bahia, Salvador/BA, já vistos na Figura 5 (um deles em destaque), e Museu Afro Brasil, São Paulo/SP (Acervo MAB 0507), em uma das reproduções fotográficas de Anibal Sciarretta / Artur Viana / Romulo Fialdini publicadas por Araujo; Moura (1994, p. 81 [autoria desconhecida]).

Há, porém, uma observação na alínea correspondente ao número de registro desse oxê que diz: "Peça africana: achava-se até março de 1956 [...] sem qualquer indicação de origem ou proveniência". A única coisa que se pode tirar disso é que essa peça não é africana, e sim brasileira, baiana e provavelmente mais recente que os três oxês do IGHBA, que, estimamos, datam de apreensões policiais entre 1930 e 1940, ainda que, também, ainda não haja delas - ou de cada uma delas - dados de proveniência precisos disponíveis. Os pequenos segmentos gomados que parecem gotejar da cabeleira de círculos concêntricos poderiam apontar para uma característica de estilo, mas, na verdade, essa forma de cabeleira simboliza, segundo alguns autores, os flamejos de xangô. Do ponto de vista estilístico, ela não nos parece ser mais importante que a postura corporal da figura humana compreendida na peça, e nisso o oxê do MAB pode ser aproximado dos dois outros 
oxês do IGHBA. Mas que seja com cautela: nestes, as mãos parecem segurar os mamilos; no oxê do MAB, como na iemanjá de Nina, isso pode ser insinuado, mas não chega a ocorrer, posicionando-se, como se vê, em figurações da imaginária católica - seria? De qualquer modo, segurar os mamilos não é um condicionante nas produções plásticas tradicionais da África apenas.

Vamos agora a estes dois outros oxês do IGHBA, a que nos parece remeter, com maior verossimilhança, um pertencente ao acervo do MAE/USP, vindo de Salvador no mesmo lote da estátua de iemanjá vista na Figura 2 e tombado em 1974 (Figura 7).

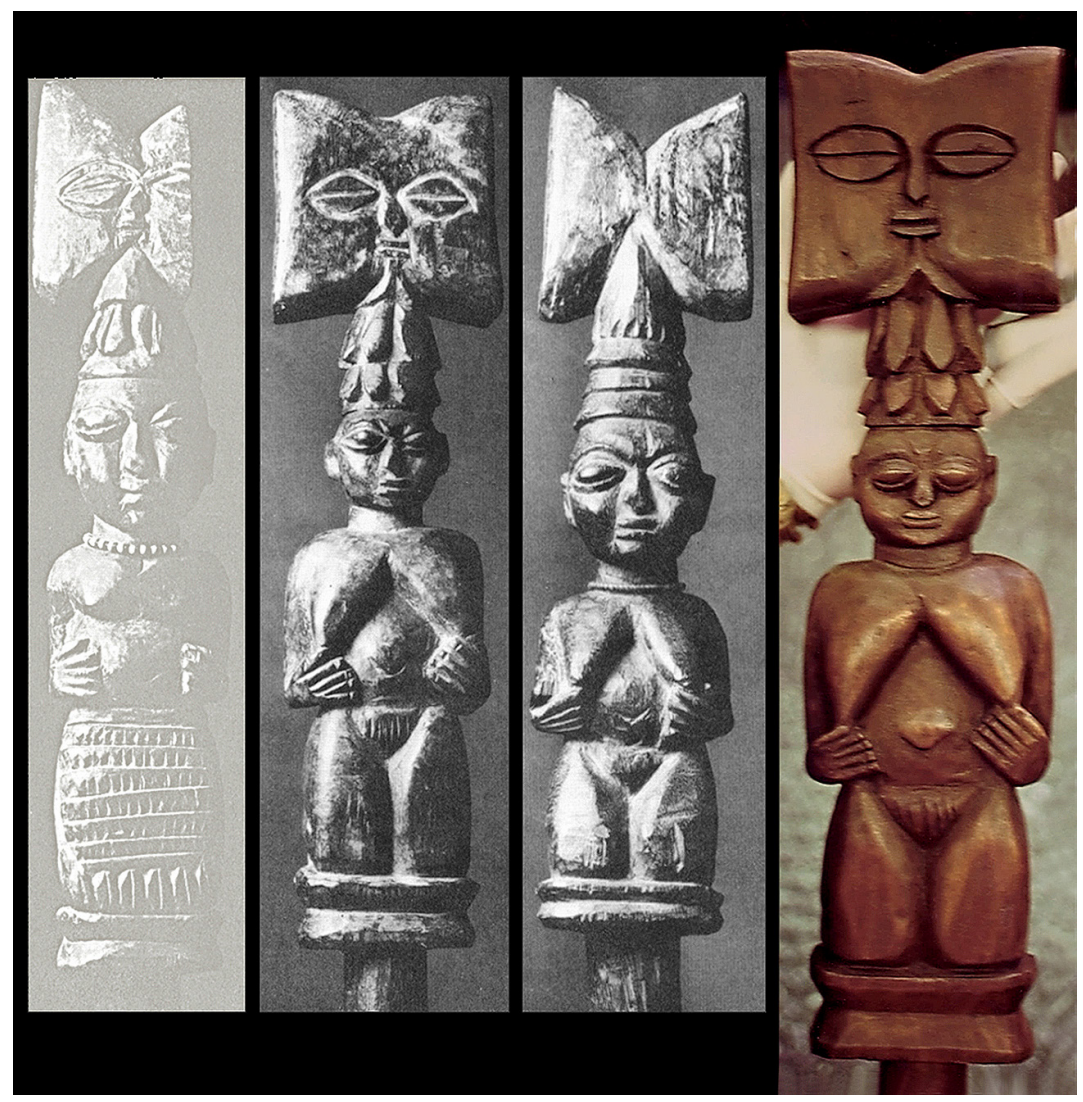

Figura 7 - Da esquerda para a direita: oxês do acervo do Instituto Geográfico e Histórico da Bahia, Salvador/BA, já vistos nas Figuras 5 e 6 (dois deles em destaque), e do Museu de Arqueologia e Etnologia da Universidade de São Paulo, São Paulo/SP, em fotografia da autora, c. 1999 (Acervo MAE/USP 74/2.10).

Consta que ele teria vindo no despacho dos últimos itens aprovados para compra pelo MAE/USP, em carta de Pierre Verger de 26 de agosto de 1971 à direção do MAE/USP: "(...) Todas as peças enviadas são da mão de Carlos Henrique Guimarães, que trabalha [...] no Museu do Unhão, salvo o oxe de Xango, feito por Georges Pflieger [...]". Esse oxê do acervo do MAE/USP là direita da figura) parece visivelmente inspirado nos outros dois do IEB destacados, 
73. Verger (1986, p. 164, fig. 129).

74. Barata (1957, p. 55).

75. Ribeiro Junior (2008, p. 80-85).

76. Lody (1985, p. 47-48, tombo 051-053, p. 119).

77. Araujo (2005, p. 113).

78. Herskovits (2008, p. i).

79. Romo (2010, p. 136).

80. Romo (2010, p. 149, n. 97), especialmente no da esquerda, que, pelo texto de Marianno, mede 40,4 cm contra os seus $50,8 \mathrm{~cm}$.

Pelo que se tem, o oxê do IGHBA a que o do acervo do MAE/USP mais se assemelha era antes conhecido apenas pela fotografia de Pierre Verger. Como a "Yemaniá" da seriação de Marianno (Figura 3), ele consta da seleção de fotografias publicadas sem data em Verger. ${ }^{73}$ Já a imagem do outro oxê do IGHBA destacado (o da direita), e publicado por Mário Barata, ${ }^{74}$ não havia aparecido novamente, senão no texto de Marianno.

Não tivemos acesso a essas peças em pesquisa junto ao IGHBA em 1988, e sabe-se que seu acervo se perdeu, ou dispersou-se em quase toda sua totalidade. ${ }^{75}$ Os três oxês do IGHBA constam do catálogo de Lody ${ }^{76}$ e, mais recentemente, dois oxês deles foram vistos na exposição "Brasileiro, brasileiros", do Museu Afro Brasil, e publicados no catálogo correspondente, ${ }^{77}$ sem que junto deles se incluísse o destacado na Figura 6.

O desconhecimento sobre a trajetória de peças de acervos antigos e o desaparecimento de muitas delas podem ter afetado também o antigo Museu do Estado da Bahia, Salvador/BA, que parece ter sido dispersado junto com sua documentação. Parte dele se mostra na reprodução da capa da primeira edição de Pesquisas Etnológicas na Bahia, datada de 1943.78 Vem de lá um curioso oxê que conferiremos mais adiante.

Anadelia Romo apresenta uma boa compreensão do papel do Museu do Estado a partir de 1939, quando assumiu sua direção José Antonio do Prado Valladares, sendo ele um dos que introduziram Herskovits nos cultos afro-brasileiros em sua estadia no Brasil em 1941 e 1942.79 Nesse período, esse museu, adotando uma missão de cunho educacional, sobressaiu-se como único entre outros museus de Salvador, que eram mantidos por organizações privadas. Através de um acervo diversificado, passou a centrar-se em ações voltadas aos processos constitutivos de uma identidade afro-baiana. À chegada dos anos 1960 e da ditadura militar, velaram-se os antigos propósitos de José Valladares, bem como os novos trazidos por Lina Bo Bardi, que assumiu a responsabilidade da parte do acervo que foi transferida para o novo Museu de Arte Moderna da Bahia (MAM/BA), Salvador. Não se tem conhecimento do destino dos "instrumentos e fetiches dos africanos" desse acervo, mas se sabe que as outras peças foram transferidas do Museu do Estado para o Convento do Carmo e para o Museu do Recôncavo Wanderley Pinho, respectivamente em Salvador e Candeias, também no Estado da Bahia, com o que o Museu do Estado tornou-se efetivamente o museu de elite que nasceu para ser. ${ }^{80}$

Mantiveram-se lá as pencas de balangandãs e as joias de ouro usadas pelas crioulas, mas não percebemos objetos de culto nesse museu, situado no bairro de Vitória, quando em visita técnica em 1995 e 1997-1998, e não vimos lá peças pertinentes ao nosso tema.

Mas já da época de sua fundação, na Era Vargas, seria possível que houvesse no Museu do Estado, como nos museus particulares baianos, outras peças de culto muito antigas, como um par de ibeji do acervo da Fundação 
Instituto Feminino da Bahia, cuja procedência provável já foi apontada como de Lagos, Nigéria, do final do século XIX, embora indícios apontem para sua feitura brasileira. ${ }^{81}$ Mas não se pode assegurar que todas as peças desses acervos tivessem igual anterioridade.

Vê-se, a partir do trecho de um documento levantado por Anadelia Romo, datado de 1939, o modo como as coleções de objetos que nos interessam aqui se nuclearam no Museu do Estado:

Nas feiras livres, nas fazendas, nos candomblés, na pequena indústria, em escolas, e também entre colecionadores particulares e entre coleções oficiais já existentes, são coligidos os objetos que devem figurar na original exposição etnográfica. (...) Todo o material recoIhido, e mais a documentação fotográfica fixada do material, deverá figurar depois no Museu do Estado. ${ }^{82}$

Ainda que, sem entrar diretamente no mérito da formação dessas coleções na época, Beatriz Góis Dantas analisa a "exaltação da tradição africana" estabelecida na Bahia entre intelectuais com lideranças de culto na década de 1930, promovendo "africanismos" - ou, como diz ela, uma "cristalização de conteúdos culturais que passam a ser tomados como expressão máxima de africanidade". ${ }^{83}$ Foi nesse período que, na Bahia, se deu o auge da repressão policial aos terreiros brasileiros e também se deram os primeiros congressos afrobrasileiros. Esses congressos são marcos desse direcionamento dos estudos sobre o negro no Brasil, e vem daí também a difusão dos exemplares ainda existentes dos antigos candomblés, retirados pela polícia e recuperados das delegacias pelos acadêmicos. É singular o peso que teve a antropologia americana nesses congressos, sobretudo se consideramos sua introdução entre nós pelo contato que fez Melville Herskovits com Arthur Ramos em virtude de objetos dos candomblés que ele houvera publicado. ${ }^{84}$ A correspondência entre Arthur Ramos e Melville Herskovits durou 14 anos, suficientes para que a orientação culturalista se arraigasse como resposta aos estudos desses objetos no Brasil, sendo responsável pela troca de conhecimento sobre África e Américas entre pesquisadores brasileiros e americanos, em suas idas e vindas entre Brasil e EUA, por longas três décadas, como mostra a documentação encerrada na Coleção Arthur Ramos do acervo digital da Fundação Biblioteca Nacional, Rio de Janeiro, que também mereceu importante análise de Antonio Sérgio Guimarães. ${ }^{85}$

Ora, José Valladares era o secretário do II Congresso Afro-brasileiro realizado em Salvador, em 1937, quando, ao que parece, providenciou peças de encomenda para Mário de Andrade, como o oxê constante na Figura 4. Será que ele também teria agenciado peças para outros estudiosos e museus, como o que aconteceu muito tempo mais tarde com relação à estátua e ao oxê xangô do acervo do MAE/USP vistos nas Figuras 2 e 7 ?

É isso que nos desperta o oxê que se vê na fotografia difundida pela publicação de Herskovits, com formas bastante peculiares (Figura 8).

Qual seria sua procedência? A resposta talvez se encontrasse no fato de que o estudioso americano tenha mantido contatos importantes anteriores com
81. Salum (2014, p. 25-26).

82. Romo (2010, p. 120).

83. Dantas (1988, p. 242243).

84. Salum (2014, p. 14-20)

85. BNdigital (2014), Guimarães (2008). 
Arthur Ramos, José Valladares e também com Heloísa Alberto Torres, diretora do Museu Nacional da Universidade Federal do Rio de Janeiro, que levou para esse museu peças do gênero no período, como já foi dito.

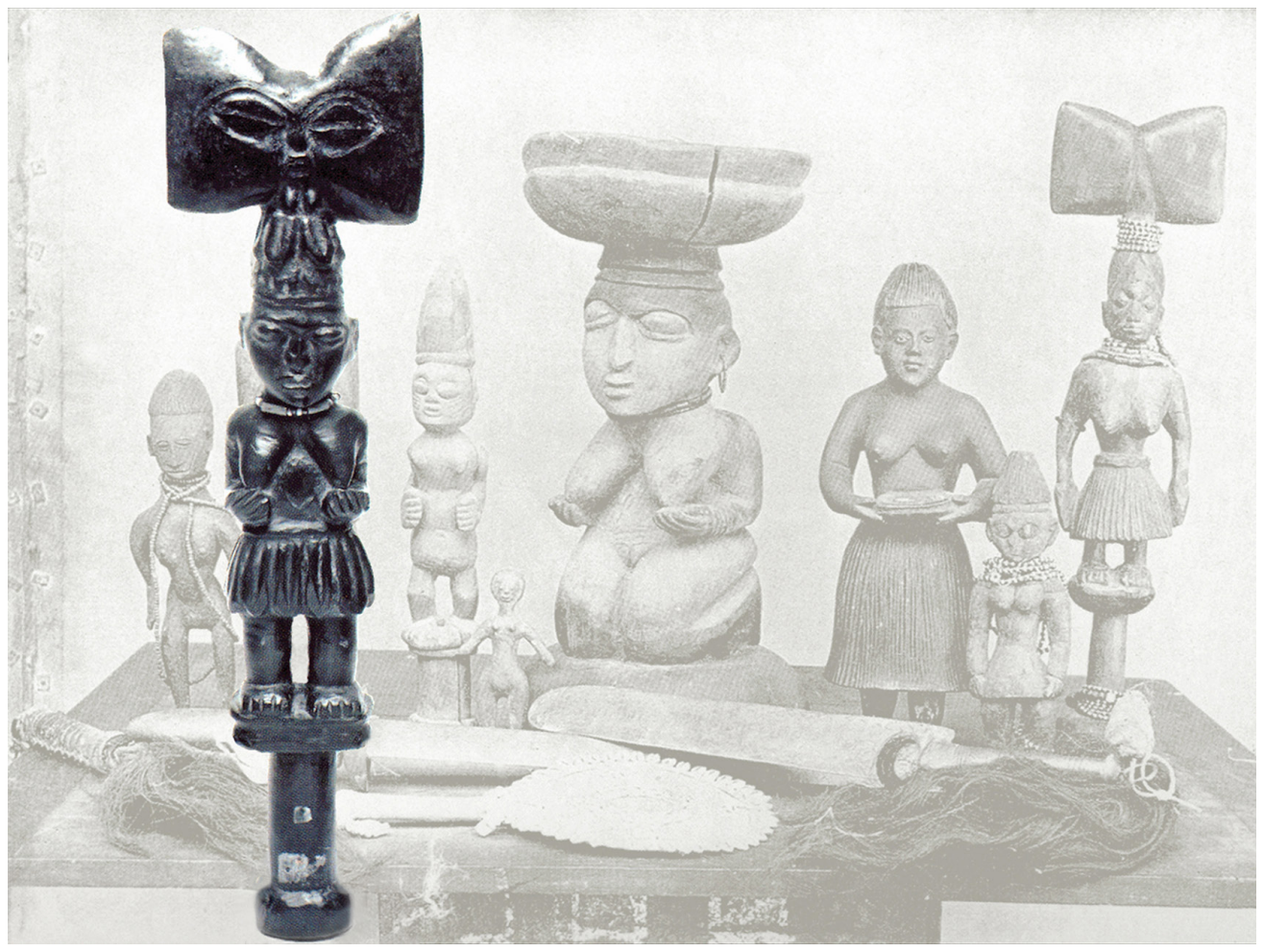

Figura 8 - Oxê publicado junto a outras peças atribuídas ao acervo do Museu do Estado da Bahia, Salvador/BA, na edição de 1943 de Pesquisas Etnológicas na Bahia (Herskovits, 2008, capa), sobreposto à fotografia publicada por Nina Rodrigues vista na Figura 1 .

O oxê do Museu do Estado da Bahia revelado por Herskovits é mais uma peça que nós juntamos como expressão do ateliê baiano apontado por Carneiro da Cunha - ou uma expressão dele derivada. Esse oxê possui os traços de estilo das peças selecionadas por Marianno. São, entretanto, nele visíveis também traços formais de outro possível ateliê afro-brasileiro: ele relembra a presença da saia plissée da estatueta de oxum da fotografia de Nina Rodrigues, reproduzida como pano de fundo dessa prancha - a penúltima peça de trás. Essa peça publicada por Herskovits é um oxê de saiote gomado.

Esse saiote não é plissado, nem liso, como é a saia do oxê do IEB de feitura nagô-iorubana, que aqui ressurge, com os mesmos seios juntos e baixos e queixo pontiagudo da última peça de trás da fotografia de Nina Rodrigues, que também veste essa saiazinha peculiar (Figura 9).

Considerando-se o imponente elemento plástico da figuração de um oxê, não parece estranho que eles sejam maioria entre as esculturas dos cultos antigos que se deram a conhecer. Será que, então, as saias podem ser assim 
importantes? Parece que sim, se nos lembrarmos das figuras assim "vestidas" e esculpidas nas superfícies de antigos pilões provenientes dos candomblés existentes em coleções, mesmo que os pilões não pertençam ao recorte de objetos de que aqui tratamos.

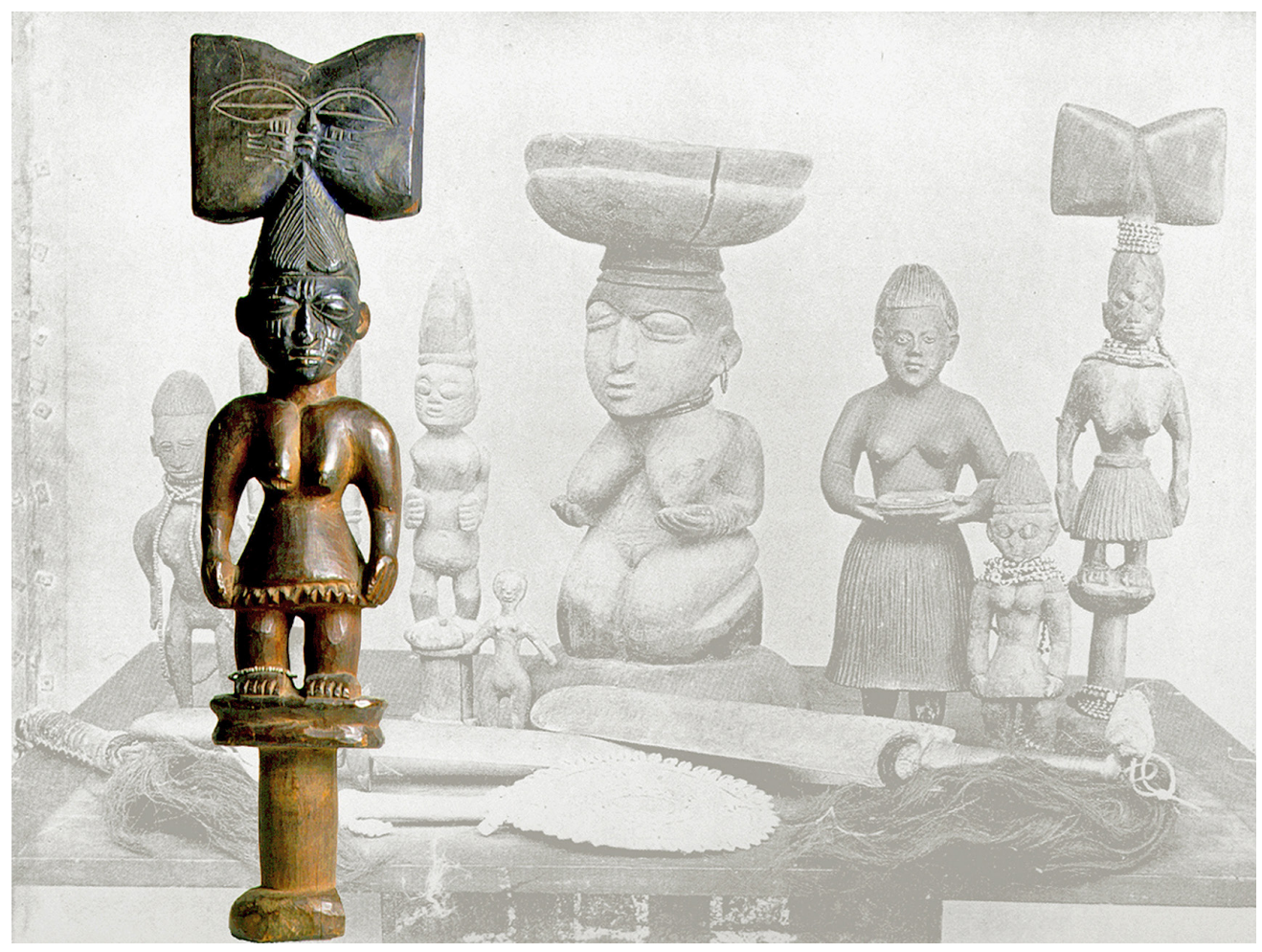

Figura 9 - "Oxê de Xangô" (Acervo IEB/USP MA-0751) do Instituto de Estudos Brasileiros da Universidade de São Paulo, São Paulo/SP (Col. MA - Col. de Artes Visuais), tomada integral em fotografia de Romulo Fialdini publicada por Batista (2004, p. 236, peça n. 751 ) já vista na Figura 4, aqui sobreposta à fotografia publicada por Nina Rodrigues vista na Figura 1.

De todo modo, essa pergunta nos vem agora diante de um outro oxê, de um estilo antigo e individual, sem par, que é o "Oxê da Xangô", publicado em Xangôs do Nordeste: investigações sobre os cultos negros fetichistas, de Gonçalves Fernandes, em 1937. Trata-se de um outro "oxê Xangô" do acervo do IEB, proveniente do Hospital Juliano Moreira, em João Pessoa/PB, e esculpido por um interno de nome Augusto. Ele foi publicado por Marta Rossetti ${ }^{86}$ e por ela atribuído ao mesmo autor do oxê publicado por Gonçalves Fernandes, dadas suas semelhanças e sua procedência: Gonçalves Fernandes assim legenda a fotografia daquele oxê: "escultura em madeira por um parafrênico do Hospital-Colônia Juliano Moreira" ${ }^{87}$

Disso nos vem nova pergunta: o saiote dessas duas peças, que é o mesmo da peça publicada por Herskovits, seria um indicativo da existência de outros estilos?

É assim que o oxê do então Museu do Estado da Bahia, de localização desconhecida e visto na Figura 8, passa a ser recolocado em uma outra perspectiva
86. Batista (2004, p. 238239).

87. Gonçalves Fernandes (1937, p. 128-129, fig. 9). 
88. Ramos (1934).

89. Barata (1988, p. 185).

além da que indicamos antes. Lá, o tomávamos na condição de um objeto a ser perfilado junto dos que representam a tradição escultórica revelada por Marianno, com a especial prerrogativa de ter sido publicado por Herskovits em 1943. Ele nos redireciona para um grupo de peças distintas das de que tratávamos e em que parece poder se incluir também. Os oxês publicados por Gonçalves Fernandes e por Marta Rossetti, por sua vez, nos remetem a um outro oxê, chamado por Arthur Ramos em Arte negra no Brasil de "Xangô em sua representação escultórica". Tratase de peça da coleção de Arthur Ramos publicada na primeira edição de $\bigcirc$ Negro brasileiro, ${ }^{88}$ mas também em obras subsequentes do autor. Lembra a "peça do culto de Ochum" publicada por Nina Rodrigues - aproximação bem observada por Mario Barata, que nelas ressalta traços em comum, como o "esquema da cabeleira e da saia 'plissé'". 89

É nessa sequência que esses cinco objetos mencionados no parágrafo anterior vão ilustrados abaixo (Figura 10).
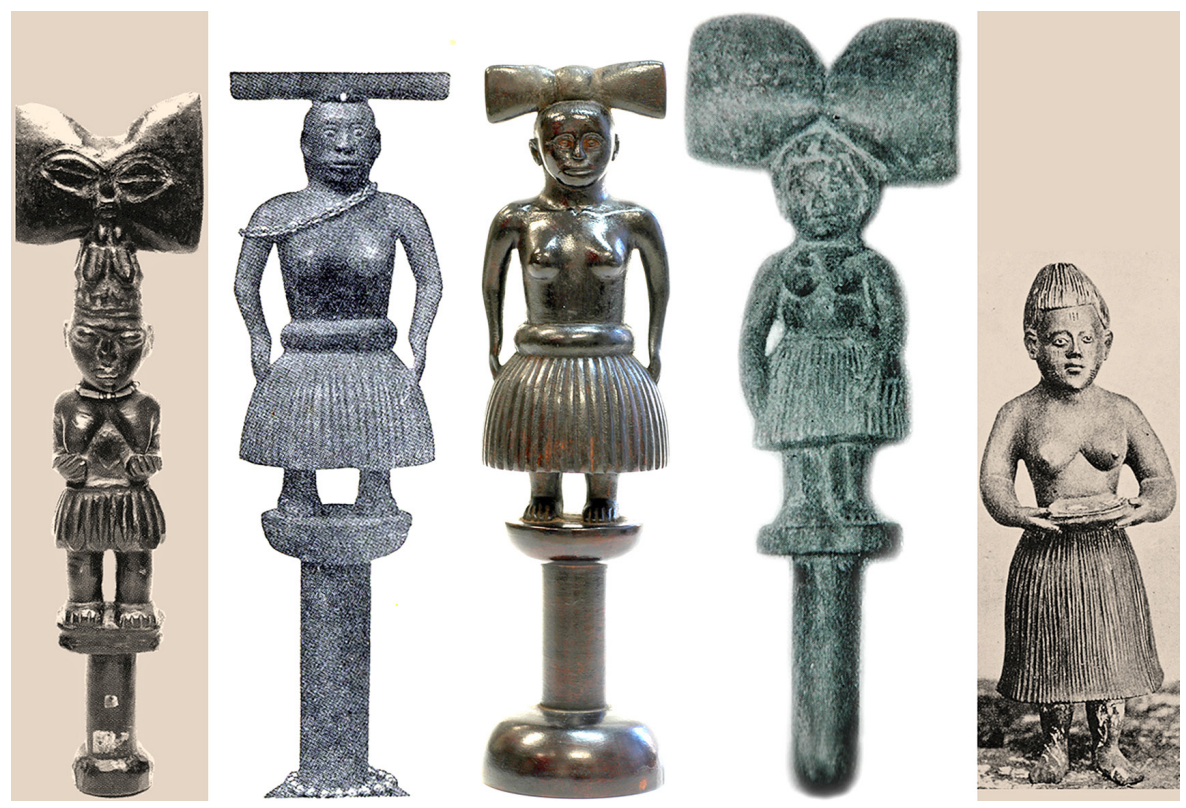

Figura 10 - Da esquerda para a direita: peça publicada como sendo do Museu do Estado da Bahia em Herskovits (2008, capa), já vista na Figura 8; "oxê da Xangô" publicado por Gonçalves Fernandes (1937, fig. 9, entre p. 128 e 129); "oxê de Xangô", de Augusto, do Instituto de Estudos Brasileiros (Col. MA - Col. de Artes Visuais IEB-USP), em fotografia de Wagner Souza e Silva tomada em colaboração com a autora, 2004 (Acervo IEB/USP MA0752); "Xangô" do acervo da Casa José de Alencar da Universidade Federal do Ceará, Fortaleza/CE (Coleção Arthur Ramos), como publicado em Ramos (1934, fig. 6, entre p. 34 e 35); e "peça do culto de Ochum" publicada em Rodrigues (2002, p. 161, fig. IV).

Primeiramente, temos a observar que, nessa figura, a "oxum" publicada por Nina Rodrigues (ver a faixa lateral direita) é a única peça a tutto-tondo, uma figura humana isolada do todo, sem complementos, como a empunhadura que compõe as demais peças, mas, de algum modo, ela está relacionada também a 
xangô e aos oxês, conforme apontamos em Salum (1 999). Suas mãos em "pinça", como as da "Yemanjá" vista na Figura 3, são extremamente afiladas, do mesmo modo que as de uma pequena peça do conjunto fotografado por Nina Rodrigues Ina fotografia constante da Figura 1, retomada em outras figuras deste artigo, é a primeira da esquerda para a direita, na fileira da frente) - seus braços recaem paralelos ao corpo, em leve e delicada postura, como de um gesto de acolhimento. Esses braços finos que terminam nessas mãos retorcidas também são os mesmos braços e mãos do oxê publicado por Gonçalves Fernandes /primeira peça no centro da Figura 101, o que é um traço escultural importante a ser investigado oportunamente, mas dificilmente as peças ilustradas nessa figura fariam parte de uma mesma tradição escultórica propriamente, apesar de acharmos elementos comuns esparsos entre elas e outras já vistas.

A peça que se segue à de Gonçalves Fernandes nessa figura là sua direita) é o outro oxê da Coleção de Artes Visuais do IEB/USP. Intrigante é a informação de que Luis Saia, tendo participado do II Congresso Afro-brasileiro, tivesse encomendado a feitura dessa peça ao interno Augusto, do Hospital Juliano Moreira, em 1938.90 Um "parafrênico" não haveria de aceitar encomenda de cópias, mas esse oxê tem tanta semelhança com o publicado por Gonçalves Fernandes - que também participou desse Congresso - que parece ter sido esculpido por alguém que copiou, de modo bem copiado e certinho demais, uma obra de aparência bem mais original que a sua, resultando nesse oxê "caprichosamente acabado", como bem observou Marta Rossetti. 91

oxê publicado por Arthur Ramos (a terceira peça, do centro da figura) pertence ao acervo da Casa de Alencar, em Fortaleza, tendo sido também publicado por Raul Lody, como as demais peças de sua coleção do autor. ${ }^{92}$ Diz Arthur Ramos em Arte negra no Brasil: "A figura da prancha IV é uma estatueta de Xangô, colhida por nós nos Candomblés da Bahia em 1925". 93 É um dos raros objetos antigos do gênero que ainda perduram. No entanto, não se conhece nenhum exemplar semelhante. Costuma-se associá-la à estatueta chamada de "peça do culto de Ochum" (na faixa da direita da figura), apontada por Nina Rodrigues como um "produto artístico mestiço" pelos seus "atributos da raça branca". 94 Tendose por referência a "ochum" de Nina Rodrigues, essa abordagem enviesada da produção escultórica foi retomada em $\bigcirc$ fetichismo dos negros no Brazil95 e perdurou até pouco antes do final do século XX com a edição revista e ampliada de A escultura de origem negra no Brasil. ${ }^{96}$

Seria mais prudente pensarmos nessas cinco peças, particularmente nos quatro oxês, como passíveis de uma seriação formal pela saia gomada em forma de meia esfera, mas não como estilo propriamente dito. Mas podemos afirmar serem, sim, esculturas interligadas entre si não apenas por formas, mas por um agenciamento que se dá paralelamente, movimentando sua produção sistêmica.

No inventário que Raul Lody fez da Coleção Arthur Ramos, podemos identificar cópias de gesso sumárias, rudes mesmo, de peças do acervo do Museu
90. Batista (2004, p. 43, 74 e 236).

91. Batista (2004, p. 74).

92. Lody (1987, p. 26 , peça 73).

93. Ramos (1949, p. 198199, fig. IV, 203).

94. Rodrigues (2002, p. 160161).

95. Brazil (1911-1912).

96. Barata (1988). 
97. Lody (1987, p. 14-15, peças 5 a 11 ).

98. Ribeiro Junior (2008, p. 83 , fig. 25).
Nacional do Rio de Janeiro. ${ }^{97}$ É sabido que Arthur Ramos conhecia aquele acervo: um dos originais dessas cópias é justamente um oxê daquele museu, cuja fotografia ele publicara já na primeira edição de $\bigcirc$ Negro Brasileiro ao lado da de seu "Xangô" - a peça, vista na Figura 10, a que ele se refere também como "Xangô em sua representação escultórica" em Arte negra no Brasil. Pois essas peças - a de sua coleção e a do MN/UFRJ - estão entre as que motivaram o interesse de Herskovits pelos estudos afro-brasileiros.

A formação de valores que esses objetos podem proporcionar - se é isso o que os referidos autores pretendiam, mas que os museus atuais oferecem não se dá, porém, sem o resgate de sua história de vida, o que nos remete, mais uma vez, à pesquisa que realizamos junto ao Mafro/UFBA entre 1995 e 1998. De lá, duas outras peças, apresentadas na antiga exposição, nos chamaram a atenção, mas somente com estudos posteriores é que viemos a compreender o que elas implicavam dentro da perspectiva analítica que aqui expomos. São estatuetas que estavam situadas em uma vitrine relativa à temática dos ibeji.

A primeira delas nos fez lembrar, pelo tipo de entalhe e por suas formas, das figuras do par de ibeji da coleção Arthur Ramos visto na Figura 4. E, é bem provável que seja ela a peça que se afigura em uma fotografia, sem data, dos arquivos do IGHBA, publicada em Ribeiro Jr. ${ }^{98}$ (Figura 11 )

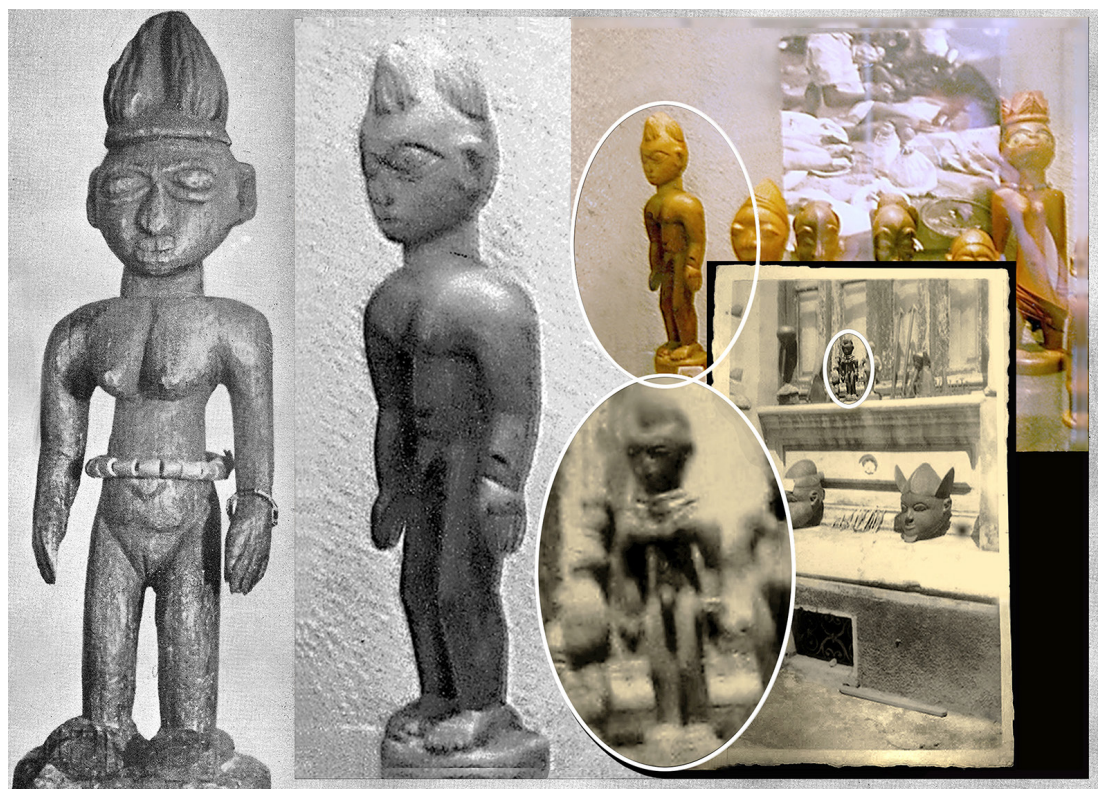

Figura 11 - À esquerda, um dos componentes do par de ibeji do acervo da Casa José de Alencar da Universidade Federal do Ceará, Fortaleza/CE (Coleção Arthur Ramos) publicado por Arthur Ramos (1949), já visto na Figura 4. No centro-direita da figura, imagem, ampliada em PxB, da estatueta disposta na vitrine relativa aos ibeji da antiga exposição do Museu Afro-brasileiro da Universidade Federal da Bahia, Salvador/BA (Acervo MAFRO/UFBA E/NEL 762), a partir de fotografia tomada pela autora (c. 1995), vista na parte superior direita. $\mathrm{Na}$ parte inferior, a mesma estatueta prefigurada no detalhe destacado da fotografia dos arquivos do IGHBA, s/d, reproduzida de Ribeiro Junior (2008, p. 83). 
Ao lado do par de ibeji de Arthur Ramos, ela aqui é vista ampliada em $P \times B$, a partir de um recorte da fotografia de uma das prateleiras da vitrine quando exposta naquele museu (acima e à direita da figura, em que essa estatueta se vê também, emoldurada por um friso branco). Parece ser ela mesma a estatueta no detalhe (na forma oval) da fotografia encontrada no IGHBA por Ribeiro Jr. (abaixo e à direita da figura), que parece ter sido tomada em uma ala do prédio do próprio instituto. ${ }^{99}$

Odorico Tavares deve ter se referido a ela quando dizia de um ibeji masculino existente no IGHBA, com remissão a uma ilustração que não corresponde a sua descrição textual, mas, lembramos, não tivemos acesso à publicação original. Parece ser ela a mencionada como "beji (ibeji) do Museu Estácio de Lima" por Marianno, sendo plausível que essa fosse uma das peças do IGHBA que estavam no Museu Estácio de Lima em sua época, antes de ser emprestada para ser exposta no Mafro/UFBA, conforme ocorreu depois.

Nesse caso, seria essa a sétima e última peça da amostragem da "tradição nagô-iorubana" referida na publicação de Marianno Carneiro da Cunha sem ilustração, que deveria ingressar na Figura 5.

Não se tem conhecimento de outra estatueta antiga que, como essa, exiba a musculatura do peito e dos braços, e tão longo comprimento das pernas desde a virilha. Tem os pés recurvados sobre a base, o que é raro nos estilos iorubanos clássicos. É coroada pela típica cabeleira das estatuetas do par de ibeji de Arthur Ramos, embora a sua seja modelada por pequenas mexas destacadas e revoltas, podendo caracterizar uma concepção individual. A posição dos braços, a feitura das mãos, a relativa isometria das partes do corpo e o formato da face - esses, sim - explicam por que facilmente seria associada àquele par de ibeji publicado por Ramos. Tavares teria razão em identificá-la como semelhante às duas estatuetas femininas que o compõem. Marianno também, ao selecioná-la como amostra, porque ela obedece aos mesmos princípios básicos da tradição escultórica das demais peças constantes em sua seriação.

Agora, não encontramos nenhum autor que se refira especificamente a um outro par de ibeji que pode ter ingressado naquele instituto depois de batida e confisco policial em 1931, de talhe muito mais afinado com o de Ramos - e de traços absolutamente compatíveis com os da seriação de Marianno. Ele ressurge de um recorte de jornal datado de 1931 (Figura 12).

A imagem do recorte de jornal também advém dos levantamentos junto aos arquivos do IGHBA e à Biblioteca Pública do Estado da Bahia realizados por Ademir Ribeiro Junior, ${ }^{100}$ tendo-se mantida inédita até que, com estímulo do próprio Ademir, viesse a ser publicada neste artigo - favoreceu-nos exercitar aqui a aplicação de um procedimento indispensável no estudo de objetos, indicado no início por Angela Lühning, entre outros autores. Vê-se que as cinco estatuetas mantêm grandes afinidades, mas as existentes entre os componentes dos pares de ibeji são exclusivas. Observa-se que foram confiscados em operações com apenas quatro anos de diferença los Arthur Ramos em 1927, como já mencionado, e estes,
99. Ribeiro Junior (2008, p. 83).

100. Ribeiro Junior (2008, p. 80-85, 125-126). 


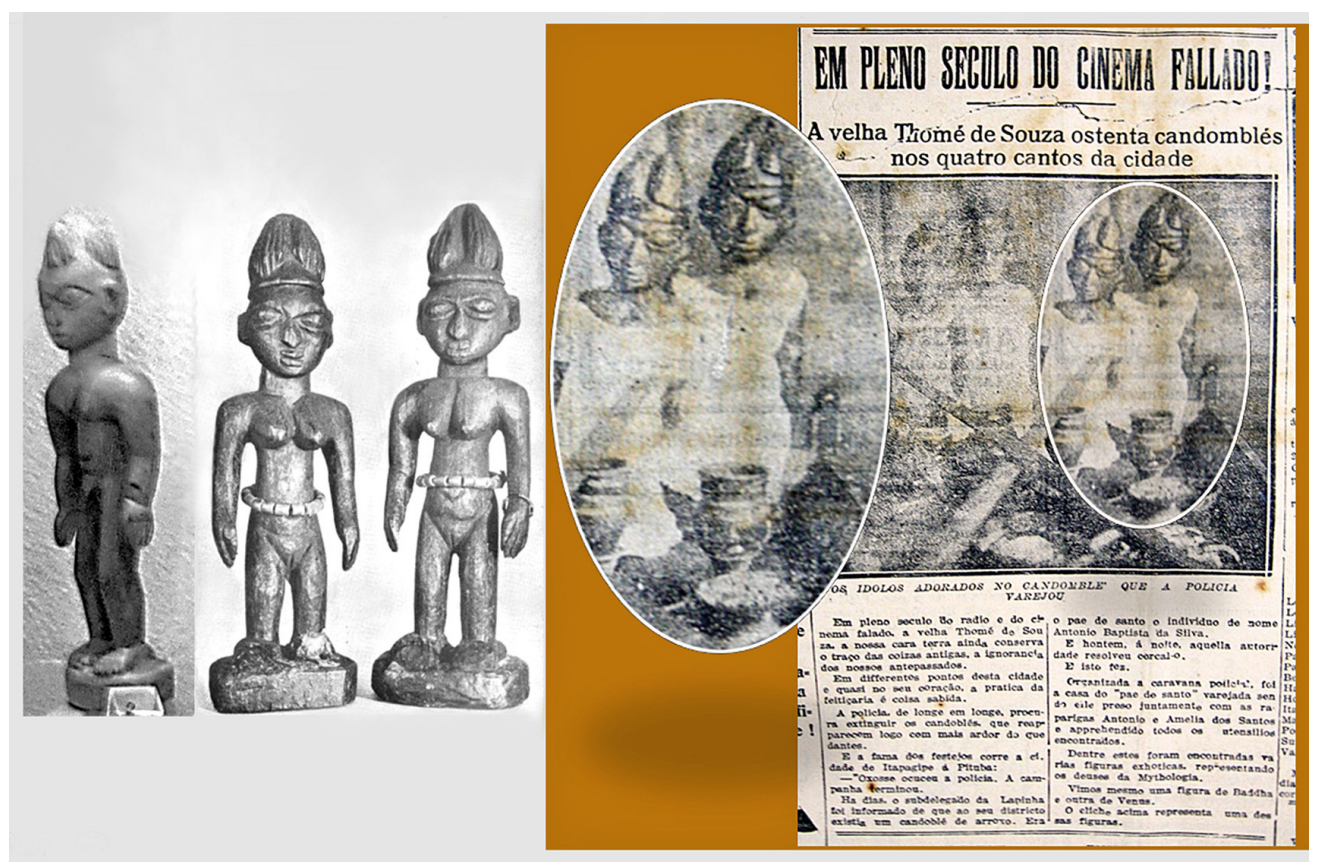

Figura 12 - À esquerda, estatueta disposta na vitrine relativa aos ibeji na antiga exposição do Museu Afro-brasileiro da Universidade Federal da Bahia, Salvador/BA em fotografia da autora já vista na prancha 11 (Acervo MAFRO/UFBA E/NEL 762), seguida pelo par de ibeji do acervo da Casa José de Alencar da Universidade Federal do Ceará, Fortaleza/CE (Coleção Arthur Ramos) publicado por Arthur Ramos (1949), já visto na Figura 4 (e, através de um de seus componentes, também na Figura 111. À direita da figura, reprodução de recorte do jornal A Tarde, Salvador (30 ago. 1931, p. 10), sobreposto por um detalhe da fotografia que veicula, na forma oval, destacando um par de ibeji confiscado de um candomblé baiano na ocasião.

do jornal, em 1931), e perfazem indiscutivelmente obra de um mesmo "ateliê", mas seria pouco provável terem sido esculpidas por um mesmo artista.

A imagem do recorte de jornal também advém dos levantamentos junto aos arquivos do IGHBA e à Biblioteca Pública do Estado da Bahia realizados por Ademir Ribeiro Junior, tendo-se mantida inédita até que, com estímulo do próprio Ademir, viesse a ser publicada neste artigo - favoreceu-nos exercitar aqui a aplicação de um procedimento indispensável no estudo de objetos, indicado no início por Angela Lühning, entre outros autores. Vê-se que as cinco estatuetas mantêm grandes afinidades, mas as existentes entre os componentes dos pares de ibeji são exclusivas. Observa-se que foram confiscados em operações com apenas quatro anos de diferença los Arthur Ramos em 1927, como já mencionado, e estes, do jornal, em 1931), e perfazem indiscutivelmente obra de um mesmo "ateliê", mas seria pouco provável terem sido esculpidas por um mesmo artista.

Para terminar este artigo, falta ainda apresentar a outra peça que, como a vista na Figura 11, chamou nossa atenção na antiga exposição do Mafro/UFBA (Figura 13). 


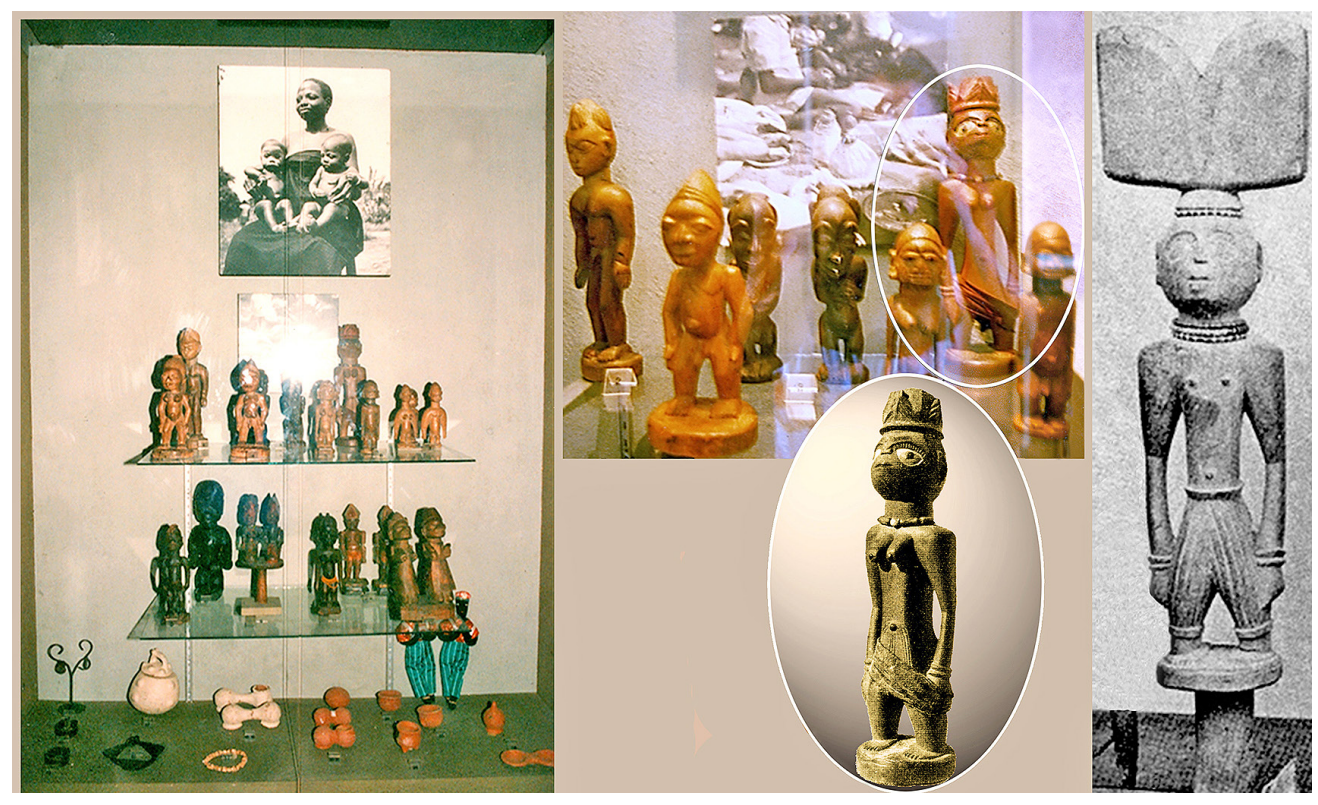

101. Carneiro da Cunha (1983, p. 1.002).

Figura 13 - Na parte esquerda da figura, tomada integral da vitrine relativa aos ibeji da antiga exposição do Museu Afro-brasileiro da Universidade Federal da Bahia, Salvador/BA, em fotografia da autora (c. 1995). Na outra, tomada de uma das prateleiras dessa vitrine já vista na Figura 11, em que se destaca a estatueta referida no texto (Acervo MAFRO/UFBA E/NEL 2831, vista também abaixo, na forma oval, em fotografia de Romulo Fialdini, reproduzida de Carneiro da Cunha (1983, p. 1.002, fig. 1.376); à direita, o "Ochê de Changô" publicado por Nina Rodrigues, em recorte da fotografia já vista na Figura 1.

À esquerda da figura se vê uma fotografia integral da vitrine. Na prateleira em que as duas se encontravam, ela se destacava por sua superfície vibrante e colorida (última estatueta da fileira de trás). Ela se parece muito com a da figura humana constituinte de um dos oxês publicados por Nina Rodrigues là direita da Figura 13). Certamente, não faz parte da tradição estilística que Marianno estipulou, mas figura em seu texto através de uma pequena fotografia (a reproduzida na forma oval, na base da figura), legendada como sendo um ibeji proveniente do candomblé de Pulquéria da coleção do Museu Estácio de Lima. ${ }^{101}$ Ora, Pulquéria é o nome da ialorixá do Terreiro do Gantois à época de Nina Rodrigues. Não se sabe dizer, relembrando que o texto de Marianno é póstumo e que ele não o havia terminado antes de falecer, se ele tinha dados concretos de sua proveniência ou se ele, assim denominando a peça, também relacionou seu estilo com o do oxê de Nina Rodrigues. É dessa mesma peça a fotografia que ilustra o texto de Odorico - aquela que não corresponde ao que ele diz sobre os ibejis que analisa -, legendada como sendo do acervo do IGHBA, embora estivesse no Mafro/UFBA quando a fotografamos. Vê-se tratar-se de mais uma peça que poderia ficar indiscriminada nesses acervos antigos. Marianno estava certo: ela, a peça da Figura 11 e a estátua "Yemaniá", da Figura 3, integram as peças que estavam no Museu Estácio de Lima, e que depois foram transferidas 

isso, pela sua singularidade e semelhança com o oxê de indiscutível procedência publicado por Nina e por não ter ainda recebido estudos específicos como muitas outras, a elegemos como mais um motivo para a ampliação do legado dos estudos de Marianno.

Há um outro agrupamento de esculturas antropomórficas de madeira, também relacionadas aos cultos afro-brasileiros, que analisamos a partir de uma fotografia publicada pelo etnólogo alemão Leo Frobenius em 1898, poucos anos antes de Nina Rodrigues publicar a sua. ${ }^{102}$ Entre elas, há outros ibejis, oxês e outras figuras relacionadas a Xangô. Estas, como as esculturas do corpus que apresentamos aqui, preconizam uma revisão dos rumos dos estudos de cultura material e da arte africana no Brasil.

\section{Observações finais}

Diante da rigidez das normas dos candomblés, que afetam a produção desses objetos, e da sincronicidade do uso de objetos antigos e atuais que, ao mesmo tempo, se verifica, devemos considerar quanto pesam seus estilos. A análise estilística é um dos procedimentos que, além de possibilitar o reconhecimento de artistas sem nome, mas passíveis de ser conhecidos através de suas obras, podem retirar essas esculturas de um corpo indiscriminado, no qual se projetam, de modo genérico, atributos mnemônicos, educativos e patrimoniais. Esses valores atribuídos aos objetos são todos importantes, mas eles não compreendem tudo o que expressam se não forem abordados também na sua individualidade.

Ao término da apresentação do corpus em que se funda este artigo, aplicase a pergunta preliminar que deve ser feita diante de todas essas esculturas relacionadas aos antigos candomblés: quais e quantas delas teriam sido feitas umas às imagens das outras e sob qual demanda? Sua interpretação é interdependente do conhecimento de como sua produção se desenvolve, na ambivalência dos contextos em que ela se dá, e compreende gestores, clientes, coletores e colecionadores - muitos deles, os estudiosos que as trouxeram à luz através de suas publicações.

Sem que isso seja considerado, essas e outras esculturas - diga-se isso de outras formas artísticas e tecnológicas de origem africana no Brasil tendem a permanecer veladas pela largueza do repertório de temas acadêmicos, de que, paradoxalmente, tornaram-se integrantes quando confiscadas de seu contexto. Ao contrário, olhando para cada uma delas, alçaremos rumos para uma melhor compreensão dos processos influentes na produção científica, cultural e artística de todos os que, como nós, voltam seu interesse para essas excepcionais criações estéticas. 


\section{Agradecimentos}

Não seria possível perceber e minimizar omissões e trechos obscuros deste texto sem as cuidadosas observações dos pareceristas ao original enviado. Vai a eles meu franco reconhecimento, esperando ter respondido, se não a todas, a algumas de suas generosas observações e recomendações. Agradeço, também, a paciência dos editores, dando-me tranquilidade para que eu pudesse adaptar o artigo às normas, o que eu não poderia ter feito sem a grande contribuição de Hélio Rosa de Miranda, que me acompanhou no trabalho de revisão do texto e de sua normalização documentária. A Wagner Souza e Silva, pelas fotografias reproduzidas nas Figuras 4, 9 e 10, e tantas outras. A Renato Araújo da Silva, pela severidade crítica mas imensa afetividade e desprendimento intelectual. A Ademir Ribeiro Junior e a Juliana Ribeiro da Silva Bevilacqua, que, como Renato, têm compartilhado comigo o estudo de coleções com o encanto e a profundidade requerida. À Lily Caporali, Marilene da Silva e Denise dal Pino, pela sensível e amorosa discussão visual da composição final das pranchas. 


\section{REFERÊNCIAS}

ABIODUN, Rowland; DREWAL, Henri; PEMBERTON II, John. The Yoruba Artist: New Theoretical Perspectives on African Arts. Washington D.C.; London: Smithsonian Institution, 1994.

ARAUJO, Emanoel (Org.). Brasileiro, brasileiros. São Paulo: Museu Afro Brasil, 2005.

. A mão afro-brasileira: significado da contribuição artística e histórica. São Paulo: Tenenge, 1988.

Para nunca esquecer: negras memórias/memórias de negros. Rio de Janeiro: Museu Histórico Nacional, 2002.

; MOURA, Carlos Eugênio Marcondes de. Afro-brasilianische Kulturund zeitgenössische Kunst $=$ Art in Afro-Brazilian religion = Arte e religiosidade afro-brasileira. São Paulo: Câmara Brasileira do Livro, 1994.

ARNOLDI, Mary Jo; GEARY, Christraud; HARDIN, Kris. African Material Culture. Bloomington: Indiana University Press, 1996. (African systems of thought).

BALANDIER, Georges. Dinâmicas sociais: sentido e poder. São Paulo: Difel, 1976.

BARATA, Mário. A escultura de origem negra no Brasil. Brasil. Arquitetura Contemporânea, Rio de Janeiro, n. 9, p. 51-56, 1957.

A escultura de origem negra no Brasil. In: ARAUJO, Emanoel. A mão afro-brasileira: significado da contribuição artística e histórica. São Paulo: Tenenge, 1988, p. 183-190 [edição ampliada do original de mesmo título, Brasil Arquitetura Contemporânea, 1957].

BARCELOS NETO, Aristóteles; ABREU, Carolina; FERREIRA, Francirosy; PAES, Francisco Simões; COLlAÇO, Janine; MAIA Ugo; FEICHAS, Vânia. África, Acre, Chicago - visões da antropologia por Manuela Carneiro da Cunha. Revista de Antropologia, São Paulo, v. 50, n. 2, p. 813-848, 2007.

BARRINGER, Tim; FLYNN, Tom (Ed.). Colonialism and the Object: Empire, Material Culture and Museum. London; New York: Routledge, 1998.

BASTIDE, Roger. Les Amériques noires: les civilisations africaines dans le nouveau monde. Paris: Payot, 1967.

BATISTA, Marta Rossetti. Coleção Mário de Andrade: religião e magia, música e dança, cotidiano. São Paulo: Edusp; Imprensa Oficial, 2004.

BEVILACQUA, Juliana Ribeiro da Silva; SILVA, Renato Araújo da. África em Artes. São Paulo: Museu Afro Brasil, 2015.

BIEBUYCK, Daniel (Ed.). Tradition and creativity in tribal art. Berkeley: University of California Press, 1969. 
BLIER, Suzanne Preston. African vodun: art, psychology, and power. Chicago: University of Chicago Press, 1995.

BNDIGITAL (Biblioteca Nacional Digital), Rio de Janeiro. Disponível em: <http://bndigital. bn.gov.br/acervo-digital>. Acesso em: maio 2014.

BRAZIL, Étienne. O fetichismo dos negros no Brazil. Revista do Instituto Histórico e Geográfico Brazileiro, Rio de Janeiro, tomo LXXIV, parte 2, p. 195-260, 1911-1912.

CARNEIRO DA CUNHA, Marianno. Arte afro-brasileira. In: ZANINI, Walter (Ed.). História geral da arte no Brasil, São Paulo: Instituto Walter Moreira Salles, 1983, p. 973-1033. 2. v.

COIMBRA, Silvia; MARTINS, Flávia; DUARTE, Letícia. O reinado da Lua: escultores populares do Nordeste. Rio de Janeiro: Salamandra, 1980.

CORNET, Joseph. African art and authenticity. African Arts, Cambridge (USA), v. 9, n. 1, p. 52-5, 1975.

CORRÊA, Mariza. Dona Heloisa e a pesquisa de campo. Revista de Antropologia, São Paulo, v. 40, n. 1, p. 11-54, 1997.

; MELLO, Januária (Org.). Querida Heloisa / Dear Heloisa: cartas de campo para Heloisa Alberto Torres. Campinas: Núcleo de Estudos de Gênero-PAGU/Unicamp, 2008. (Série Pesquisa).

D'AZEVEDO, Warren (Ed.). The traditional artist in African society. Bloomington: Indiana University Press, 1973.

DANTAS, Beatriz Góis. Vovó Nagô e Papai Branco: usos e abusos da África no Brasil. Rio de Janeiro: Graal, 1988.

DANTO, Arthur Coleman; GRAMLY, Richard Michael; HULTGREN, Mary Lou; SCHILDKROUT, Enid; ZEIDLER, Jeanne. Art/Artifact: African Art in Anthropology Collections. New York: The Center for African Art; Prestel-Verlag, 1988.

DE GRUNNE, Bernard (Ed.). Masterhands. Afrikaanse Beeldhouwers in de Kijker = Masterhands. Mains De Maîtres. À la découverte des sculptures d'Afrique. Bruxelles: Espace Culturel BBL, 2001.

DE MARET, Pierre; DERY, Nicole; MURDOCH, Cathy. The Luba Shankady Style. African Arts, Cambridge (USA), v. VII, n. 1, p. 8-15, 1973.

EDWARDS, Elisabeth. Anthropology and photography, 1860-1920. New Haven: Yale University Press, 1997.

EYO, Ekpo. Conventional Museums and the Quest for Relevance in Africa. History in Africa, New York, v. 21, 1994, p. 325-337.

FAGG, William. A Master Sculptor of the Eastern Congo. Man, London, v. 48, p. 36-38, 1948. The african artist. In: BIEBUYCK, Daniel (Ed.). Tradition and Creativity in Tribal Art. Berkeley: University of California, 1969, p. 42-57. 
FAIllaCE, Vera Lúcia Miranda (Org.). Arquivo Arthur Ramos: Inventário Analítico. Rio de Janeiro: Edições Biblioteca Nacional, 2004. (Coleção Rodolfo Garcia, 30).

FROTA, Lélia Coelho. Pequeno Dicionário da Arte do Povo Brasileiro: século XX. Rio de Janeiro: Aeroplano, 2005.

GONÇALVES FERNANDES, Albino. Xangôs do Nordeste: investigações sobre os cultos negrofetichistas do Recife. Rio de Janeiro: Civilização Brasileira, 1937. (Biblioteca de Divulgação Científica, 13).

GOSSIAUX, Pierre. Les maîtres de Buli: esthétique et ethno-histoire (avec deux inédits). Art et exotisme, Revue des historiens de l'art, des archéologues, des musicologues et des orientalistes de l'Université de Liège, Liège, n. 9, p. 38-49, 1990.

GUIMARÃES, Antonio Sérgio Alfredo. Africanism and Racial Democracy: the Correspondence between Herskovits and Arthur Ramos (1935-1949). Estudios Interdisciplinarios de América Latina y el Caribe, Tel Aviv, v. 19, n. 1, p. 53-79, 2008.

HASELBERGER, Herta. Method of Studying Ethnological Art. Current Anthropology, Chicago, v. 2, n. 4, p. 341-384, 1961.

HERSKOVITS, Melville. Dahomey: an ancient West African kingdom. New York: J. J. Augustin, 1938. 2. v.

Pesquisas etnológicas na Babia. Salvador: Museu de Arte da Bahia, 2008, p. 13-36 [reprodução do original de mesmo título, Publ. do Museu da Bahia n. 3, Salvador, Secretaria de Educação e Saúde, 1943].

HOUNTONDJI, Paulin. Conhecimento de África, conhecimento de africanos: duas perspectivas sobre os Estudos Africanos. Revista Crítica de Ciências Sociais, Coimbra, n. 80, p. 149-160, 2008. Disponível em: <https://rccs.revues.org/69>. Acesso: nov. 2016.

IPEAFRO (Instituto de Pesquisas e Estudos Afro-Brasileiros). Disponível em: <http://www. abdias.com.br/museu_arte_negra/abdias_man.htm>. Acesso: out. 2015 [reprodução do original de Abdias do Nascimento, intitulado Cultura e estética no Museu de Arte Negra, Revista GAM, Rio de Janeiro, 1968].

KAMER, Henri. De authenticité des sculptures africaines. Arts d'Afrique Noire, n. 12, p. 17-40, 1974.

KASFIR, Sidney. Arte africana e autenticidade: um texto com uma sombra [publicado em fev. 2008]. Disponível em: <http://www.artafrica.info/novos-pdfs/artigo_14-pt.pdf>. Acesso em: maio 2014.

LODY, Raul. Coleção Arthur Ramos. Rio de Janeiro: Funarte/lnstituto Nacional do Folclore; Fortaleza: UFCe, 1987.

O Negro no museu brasileiro: construindo identidades. Rio de Janeiro: Bertrand Brasil, 2005.

. Um documento do Candomblé na cidade do Salvador. Salvador: Fundação Cultural do

Estado da Bahia; Rio de Janeiro: MinC/FUNARTE/INF, 1985. (Coleção culto afro-brasileiro). 
LÜHNING, Angela. Acabe com este Santo, que Pedrito vem aí... . In: DOSSIÊ POVO NEGRO - 300 ANOS. Revista USP, São Paulo, n. 28, 1995-1996, p. 194-220.

MATOS, Thiara. Correspondências pessoais ajudam a criar instituições: Pierre Verger, o Museu Afro-brasileiro e sua rede de colaboradores (1972-1976). Salvador, 2012. 178 f. Dissertação (Mestrado em Estudos Étnicos e Africanos) - Faculdade de Filosofia e Ciências Humanas, Universidade Federal da Bahia, Salvador.

MAUSS, Marcel. Ensaio sobre a dádiva: forma e razão da troca nas sociedades arcaicas. In: . Sociologia e Antropologia. São Paulo: Editora Pedagógica e Universitária; Edusp, 1974,

p. 37-184. 2. v. (1. ed. L’Année Sociologique, Paris, 1923-24).

MENESES, Ulpiano Toledo Bezerra de. Memória e cultura material: documentos pessoais no espaço público. Estudos Históricos, Rio de Janeiro, v. 11, n. 21, p. 89-103, 1998.

MUNANGA, Kabengele. Antropologia africana: mito ou realidade? Revista de Antropologia, São Paulo, v. 26, p. 151-160, 1983.

. Arte afro-brasileira: o que é, afinal? = Afro-Brazilian Art: what is it, after all?. In: AGUILAR, Nelson (Org.). Arte Afro-Brasileira = Afro-Brazilian Art. São Paulo: Associação Brasil 500 Anos Artes Visuais; Fundação Bienal de São Paulo, 2000, p. 98-111.

NEYT, François. La grande statuaire hemba du Zaire. Louvain-la-Neuve: UCL, 1977. (Publ. D'Histoire de l'Art et d'Archéologie de l'UCL, 12).

OLBRECHTS, Frans. Les arts plastiques du Congo Belge. Bruxelles: Editions Erasme, 1959. [edição francesa do original em flamengo, Antwerpen, Standaard-Boekhandel, 1946].

PINHEIRO, Lena Vania Ribeiro; GONZALEZ DE GOMEZ, Maria Nélida (Org.). Interdiscursos da ciência da informação: arte, museu e imagem. Rio de Janeiro; Brasília: Ibict/DEP/DDI, 2000. Disponível em: <http:/livroaberto.ibict.br/handle/1/443>. Acesso em: jan. 2016.

PRICE, Sally. Arte primitiva em centros civilizados. Rio de Janeiro: UFRJ, 2000.

RAFAEL, Ulisses; MAGGIE, Yvonne. Sorcery objects under institutional tutelage: magic and power in ethnographic collections. Vibrant: Virtual Brazilian Anthropology, Brasília, v. 10, n. 1, p. 276342, 2013. Disponível em: <http://www.scielo.br/scielo.php?script=sci_arttext\&pid=S180943412013000100014\&lng=en\&tlng=en. 10.1590/S1809-43412013000100014>. Acesso em: maio/jun. 2014.

RAMOS, Arthur. Arte negra no Brasil. Cultura, Rio de Janeiro, Ministério de Educação e Saúde, ano 1, n. 2, p. 189-212, 1949.

O Negro brasileiro: ethnographia religiosa e psychanalyse. Rio de Janeiro: Civilização Brasileira, 1934. (Bibliotheca de Divulgação Scientífica, 1).

RIBEIRO JUNIOR, Ademir. Parafernália das mães-ancestrais: as máscaras gueledé, os edan ogboni e a construção do imaginário sobre as "sociedades secretas" africanas no Recôncavo Baiano. São Paulo, 2008. 159 f. Dissertação (Mestrado em Arqueologia) - Museu de Arqueologia e Etnologia, Universidade de São Paulo. 
RODRIGUES, Raimundo Nina. As bellas-artes nos colonos pretos do Brasil: a esculptura. In: ARAUJO, Emanoel. Para nunca esquecer: negras memórias/memórias de negros. Rio de Janeiro: Museu Histórico Nacional, 2002, p. 158-163. [reprodução do original de mesmo título, Revista Kosmo, Rio de Janeiro, ano I, n. 8, 1904].

Os africanos no Brasil. São Paulo: Editora Nacional, 1935. (Biblioteca Pedagógica Brasileira, série V, Brasiliana, IX).

ROMO, Anadelia. O que é que a Bahia representa? O Museu do Estado da Bahia e as disputas em torno da definição da cultura baiana. Afro-Ásia, Salvador, UFBA, n. 39, p. 115-151, 2010.

RUBIN, William (Ed.). "Primitivism" in 20th century art: affinity of the tribal and the modern. New York: Museum of Modern Art, 1984. 2. v.

SALUM, Marta Heloisa Leuba. Cem anos de arte afro-brasileira = One Hundred Years of AfroBrazilian Art. AGUILAR, Nelson (Org.). Arte Afro-brasileira = Afro-Brazilian Art. São Paulo, Fundação Bienal de São Paulo; Associação Brasil 500 Anos Artes Visuais, 2000, p. 112-121. (Mostra do Redescobrimento).

. Critérios para o tratamento museológico de peças africanas em coleções: uma proposta de museologia aplicada (documentação e exposição) para o Museu Afro-Brasileiro. Revista do Museu de Arqueologia e Etnologia, São Paulo, kosmon. 7, p. 71-86, 1997.

Estilos de escultura em peregrinação: marcas de um Brasil africano ou de uma África brasileira em objetos de museu. Textos escolbidos de cultura e arte popular, Rio de Janeiro, v. 11, n. 1, p. 9-32, 2014.

Por que são de madeira essas mulheres d'água? Revista do Museu de Arqueologia e Etnologia, São Paulo, n. 9, p. 163-193, 1999.

; BEVILACQUA, Juliana Ribeiro da Silva. African art in Brazilian Museums: an Overview and Critique. Comunicação. Arts Council of the African Studies Association's 15th Triennial Symposium on African Art, Los Angeles, 2011.

; CERAVOLO, Suely. Considerações sobre o perfil da Coleção Africana e Afro-Brasileira no MAE-USP. Revista do Museu de Arqueologia e Etnologia, São Paulo, n. 3, p. 67-85, 1993.

SANSI-ROCA, Roger. De armas do fetichismo a patrimônio cultural: as transformações do valor museográfico do Candomblé em Salvador da Bahia no século XX. In: ABREU, Regina; CHAGAS, Mário de Souza; SANTOS, Myrian Sepúlveda dos (Org.). Museus, coleções e patrimônios: narrativas polifônicas. Rio de Janeiro: Garamond; MinC/IPHAN/DEMU, 2007, p. 95-112.

SCHIFFER, Michael. Archaeological Context and Systemic Context. American Antiquity, Washington D.C., v. 37, n. 2, p. 156-165, 1972.

SILVA, Renato Araújo da. Estudo da documentação do acervo africano e afro-Brasileiro do MAE-USP. São Paulo: Museu de Arqueologia e Etnologia da Universidade de São Paulo, 2004. Relatório (Iniciação Científica em Etnologia Africana). 
SMIT, Johanna (Org.) Análise documentária: a análise da síntese. Brasília: Ibict, 1987.

SOARES, Mariza de Carvalho; LIMA, Rachel Corrêa. A Africana do Museu Nacional: história e museologia. In: AGOSTINI, Camila (Org.). Objetos da escravidão: abordagens da cultura material da escravidão e seu legado. Rio de Janeiro: Sete Letras. 2013, p. 337-359.

STEINER, Christopher Burghard. African Art in Transit. Cambridge (USA): Cambridge University Press, 1999.

TAVARES, Odorico; VERGER, Pierre. A escultura afro-brasileira na Bahia. In: ARAUJO, Emanoel (Org.). Modernidade - Coleção de Arte Brasileira Odorico Tavares. São Paulo: Museu Afro Brasil, 2013, p. 50-59. [reprodução do original de mesmo título, Revista O Cruzeiro, Rio de Janeiro, 14 de abril de 1951].

THOMPSON, Robert Farris. Face of the gods: art and altars of Africa and the African Americas. New York: Museum for African Art; Munich: Prestel, 1993.

. Flash of the spirit: African and Afro-American art and philosophy. New York: Vintage Books, 1984.

VALLADARES, Clarival do Prado. O negro brasileiro nas artes plásticas. Cadernos Brasileiros, Rio de Janeiro, v. X, n. 47, p. 97-109, 1968.

VERGER, Pierre. Flux et reflux de la traite des nègres entre le golfe de Benin et Babia de todos os santos du dix-septième au dix-neuvième siècle. Paris: Mouton, EHESS, 1968. (Le mond d'Outre-Mèr passé et présent, 30).

Notas sobre o culto aos orixás e voduns na Babia de Todos os Santos, no Brasil, e na antiga Costa dos Escravos, na África. São Paulo: Edusp, 1999.

Orixás: deuses iorubás na África e no Novo Mundo. Salvador: Currupio; São Paulo:

Círculo do Livro, 1986.

VOGEL, Susan Mullin. The Buli Master, and Other Hands. In: BERLO, Janet Catherine Berlo; WILSON, Lee Anne (Eds.). Arts of Africa, Oceania, and the Americas: selected readings. Englewood Cliffs, NJ: Prentice Hall, 1993, p. 68-75.

Know Artists but Anonymous Works: Fieldwork and Art History. In: AUTHORSHIP IN AFRICAN ART, part 2. African Arts, Los Angeles, v. 32, n. 1, p. 40-55; 93-94, 1999.

WALKER, Roslyn Adele. Anonymous has a name: Olowe of Ise. In: ABIODUN, Rowland; DREWAL, Henri; PEMBERTON II, John. The Yoruba Artist: New Theoretical Perspectives on African Arts. Washington D.C.; London: Smithsonian Institution, 1994, p. 91-106.

ZANINI, Walter (Ed.). História geral da arte no Brasil. São Paulo: Instituto Walter Moreira Salles, 1983. 2. v.

Artigo apresentado em 04/11/2016. Aprovado em 29/06/2017 